\title{
Analysis of bribery predictors for the student population. Evidence from Romania and Moldova
}

\author{
Aurelian-Petruș PLOPEANU*, Daniel HOMOCIANU**
}

\begin{abstract}
This study analyzes the bribery acceptance propensity. We used 5072 responses from students in economics (seven universities from the Republic of Moldova and two Romanian regions). We wanted to see communism's impact on this inclination from east to west in territories with Romanian origins. We used purposive sampling, Data Mining, OLS, and Logit regressions with marginal effects and prediction nomograms. Theoretically, we found that proximity to Western countries matters for explaining differences between models. We also discovered strong common influences: competition (negative and mightier for Central-Western Romania), accepting undue advantages, and the immoral act of buying stolen goods (both positive and more potent for Moldova). We additionally identified peculiarities: the desire to become an entrepreneur, anti-democratic attitudes, attitude towards the interventionist role of the state in the economy, nepotism, tax evasion behaviour, inherited sense of responsibility, altruism, and hard work, mother's faith in God, interpersonal trust and individual freedom.
\end{abstract}

Keywords: bribery, historical regions, data mining, logit and OLS regressions, risk prediction nomograms

\section{Introduction}

Due to its complexity, corruption is a very difficult term to define. Despite a large set of explanations available, the concept has various facets that still induce confusion. An authoritative definition, according to which the phenomenon of corruption represents "the abuse of entrusted power for private gain" (Transparency International, 2017). Furthermore, we take into consideration a particular and, we

\footnotetext{
* Aurelian-Petrus PLOPEANU is Researcher at the Instittute of Interdisciplinary Research, Humanities and Social Sciences Research Department, Alexandru Ioan Cuza University, Iasi, Romania; e-mail: aplopeanu@gmail.com.

${ }^{* *}$ Daniel HOMOCIANU is Lecturer at Department of Accounting Business Information Systems, and Statistics, Faculty of Economics and Business Administration, Alexandru Ioan Cuza University, Iasi, Romania; e-mail: daniel.homocianu@uaic.ro.
} 
may add, the most common facet of corruption, namely bribery (Georgieva, 2017; Nam, 2018). According to Rose-Ackerman (1999), a definition of a bribe is a payment, in money or kind that involves a reciprocal obligation and aims at inducing the unethical behaviour of the person receiving bribes.

For policymakers and overall civil society, corruption seems to be an endemic and pernicious phenomenon. Sometimes is even seen as a curse. It can also appear as a profound social illness without an obvious remedy. It generates lower economic growth (Johnson et al., 2011), higher poverty rates, inequality (Jong-Sung and Khagram, 2005), and lower foreign investment (de Jong and Bogmans, 2011). It also distorts the trade, generating political instability and poor public governance efficiency (Ko and Samajdar, 2010, pp. 508-509) and affecting the quality of democracy (Villoria et al., 2013) and the levels of life satisfaction (Rodríguez-Pose and Maslauskaite, 2012). Also, it increases transaction costs (Zhang, 2009), undermining interpersonal and institutional trust (Mishler and Rose, 2001). It is a fact that, at the micro-level, corruption generates frustrations and anxiety regarding the interaction with public institutions' quality and efficiency (Uslaner and Badescu, 2004). Therefore, fighting against corruption is universal. It is also seen as one of the most important objectives to reach to generate sustainable development for generations.

This article aims to investigate the influence of personal and inherited characteristics on the acceptance of the act of bribery. We do this to understand better the role of non-pecuniary factors that may influence this corrupt phenomenon across three historical regions, being aware of the fact that any individual decision-making highly depends on a set of historical, institutional, cultural, social, or legal determinants (Cameron et al., 2009). Our paper considers three particular provinces which were under the rule of various former empires (e.g., the Ottoman, Russian or Habsburg ones). It is about Central-Western Romania (composed of historical regions, such as Transylvania, Crișana, Maramureș, Banat, and North-Western Bucovina), Southern and Eastern Romania (Moldova and Wallachia), and the Republic of Moldova. The reason for choosing them relies on the fact that none of the identified articles considered this regional distribution of respondents according to their previous belonging to a particular long-gone empire. The Habsburg Empire dominated different parts from Central and Western Romania until 1918, Moldova and Wallachia were dependent on the Ottoman Empire until the middle of the 19th century, when they first united and formed the United Principalities and, later, the Kingdom of Romania. In the Republic of Moldova, the Ottoman Empire ruled for the most part. Between 1812 and 1917, the same did the Russian one. Another reason for choosing these regions is related to the inter-regional differences between them in terms of economic development. We mean those existing back in 1918 (when the last major Empire, namely the Habsburg one, ceased to exist) and the ones manifesting nowadays. For instance, the Republic of Moldova (Bessarabia) was and still is the least developed region, while Romanian regions presented particular trends, still visible today. Many authors emphasize the superiority of the former 
Habsburg territories over Moldova and Wallachia in terms of economic development (Tudor and Matis, 2010). Other recent processed statistics underline the idea that the former Kingdom of Romania recorded better macroeconomic indicators when compared to the provinces incorporated in 1918 - the Great Union year (Schulze, 2007; Markevich, 2019; SEEMHN, 2014).

We further investigate if individual subjective mentalities, attitudes, preferences, and inherited values matter and to which extent. For instance, we are aware of the fact that the belonging of a particular region to the former Habsburg Empire may have echoes until today in terms of trust in public institutions (Becker, 2005). Therefore, we are interested in analysing if individual attitudes differently influence bribe payments depending on whether their residences' locations belong to a peculiar former empire (e.g., Ottoman, Russian or Habsburg Empire). It is a fact that a society with a high level of corruption or injustice promotes these at the individual level (Ramamoorthy et al., 2015). Moreover, we explore the elements behind the decision to engage in bribery in an environment with a lower level of corruption (Romania) in comparison with the Republic of Moldova, knowing that, in 2018, according to Transparency International' Corruption Perception Index, the latter was ranked 117th out of 180 countries, while Romania (RO) was ranked 61st.

Based on the previous report, the perception of corruption is still alarming and even increased. And this when compared with the one from a year before. In 2018, many social demonstrations against the government took place in Romania. These protests augmented because of the fear that the current government attacked the rule of law, abiding from the road to transparent and efficient public institutions. Therefore, Romania ranks among the five most corrupt countries in the European Union. A recent report from the Commission ${ }^{1}$ to the European Parliament and the Council (2018) emphasizes a notable fact. The fight against corruption should strengthen since the risk to take backward steps increased. And this because of the recent justice reforms in Romania. They made all the progress in the last years fade away.

By analysing the subjective individual attitudes and preferences that may influence the attitude towards the acceptance of bribes, this study fills a gap in the specialized literature. Also, it enriches our understanding of corruption, particularly in Romania, by considering the internal influences, otherwise very difficult to measure, that may affect the attitude towards such behaviour.

The remaining part of the paper has four sections:

- Section 2 describes the relevance of the literature review concerning our topic.

- Section 3 explains the data and methods used to test our hypotheses.

- Section 4 discusses the previous empirical analysis.

\footnotetext{
${ }^{1}$ Report from the Commission to the European Parliament and the Council (On Progress in Romania under the Cooperation and Verification Mechanism), (retrieved from https://ec.europa.eu/info/sites/info/files/progress-report-romania-2018-com-2018-com2018-851_en.pdf).
} 
-Section 5 emphasizes the conclusions, the limitations of our study, and the implications of the results.

\section{Literature review}

The literature on the topic of bribery is approached from several perspectives. Bribery is considered an immoral behaviour for societies for the simple fact that it violates the divine paradigm on earth (Logue, 2005). This fact appears in the Holy Bible, in the Book of Deuteronomy (10: 17): "For the Lord, your God is God of gods, and Lord of lords, the great God, mighty and awesome, who shows no partiality nor takes a bribe" 2 . It is also unethical because it breaks the principle of reciprocity in terms of trust and promise (Carson, 1987). Other scholars neglect these ethical rules, indicating that such corrupt behaviour occurs due to institutional failures (Colombatto, 2003).

The literature on bribe propensity has improved to a certain extent, it is still a topic insufficiently explored, especially at the individual level (De Jong and Van Ees, 2014). Usually, at the micro-level, the models regarding this topic take into consideration the theory of planned behaviour (Ajzen, 1985; 1991). The latter exhibits the intention presence, predated by subjective values, norms, and attitudes, which further influence the unequivocal decision. Some scholars (Madden et al., 1992, p. 3) also stated that behavioural intentions, which are the immediate antecedents to behaviour, are a function of salient information or beliefs about the likelihood that performing a particular behaviour will lead to a specific outcome. Moreover, they emphasized that behavioural beliefs represent the underlying influence on an individual's attitude toward performing the behaviour. In contrast, normative beliefs influence the individual's subjective norm about performing the behaviour.

The overwhelming effect of automatic thinking over the rational one also appears in the literature (Stahl et al., 2017). Zaloznaya (2014) stated that in a society where the act of corruption is the mighty norm, individuals tend to be more corrupt because they consider such behaviour normal. Frank and Schulze (2000, p. 110) state that "Students do not alter their attitude towards corruption as they progress through university, regardless of whether they are students of economics or any other field. The latter contradicts the notion that the more self-interested behaviour of economists is a result of economic education. It rather supports the self-selection hypothesis."

Ćábelková and Hanousek (2004) consider that corruption perceptions have the potential to strengthen or reduce real corruption. They encourage or not individuals to pay or not bribes. When conducting quantitative research in Ukraine, the same authors found the following. If a person considers that an institution is highly corrupt,

\footnotetext{
${ }^{2}$ Holy Bible, Bucharest: Publishing House of the Bible and Orthodox Mission Institute, 2019.
} 
they are more likely to pay bribes in certain situations. Therefore, he stimulates and perpetuates the entire phenomenon associated with corruption.

Hauk and Saez-Marti (2002) stated that individuals with certain culturallyrooted or socially embedded patterns of corrupt actions act and, hence, they finally create a rotten environment. The reciprocity (Shen et al., 2011) and diffusion of responsibility (Mazar and Aggarwal, 2011), as examples of deeply rooted values, are variables that increase the intention to receive and pay bribes (Barr and Serra, 2010). Regarding incentives, opportunities, and norms, Gorsira et al. (2016) found that individuals who are more likely to act in a corrupt way are doing this because of a cocktail of motives, from earnings to pleasure, and no fear towards legal constraints.

The activity of buying stolen goods is considered illicit. It becomes stimulated when the people's perceptions of judicial independence are distorted or suffer considerable depreciation (Mocan et al., 2020). This act is also condemned by regular church attenders or even by certain religious denominations. Therefore, it is not morally and religiously frequentable (Woodberry, 2008). Moreover, the decision to avoid paying public taxes because of their high percentage is considered a way of engaging in bribery. And this because is evident that easy and transparent access to resources (e.g., for firms) not accessible in the absence of a coherent legislative framework depends on such a rational behaviour (Yan and Qi, 2020).

Different other variables seem to be mighty triggers for bribery. For instance, the stimulating effect of the competition is one of them. In the literature, we found that an increased level of competition among public officials and bureaucrats usually reduces the practices associated with bribery (Ryvkin and Serra, 2020). Quite interesting, it offers incentives for those willing to pay bribes to follow all the instructions to obtain the legal document instead of inflating corruption (Drugov, 2010). Furthermore, from other perspectives, we have chosen the variable related to one's intentions to become an entrepreneur. And this since there is much evidence for a negative relationship between entrepreneurial likelihood and the subjective perceptions regarding the level of corruption from a chosen environment (Ghura et al., 2019).

In many developing countries, politicians try to gain votes by emphasizing that the corruption phenomenon, including bribery, must be eradicated. Although many civilians understand the endemic problem brought by such pernicious acts, they tolerate it, continuing to pay or receive bribes in certain situations. This tolerant attitude can explain itself through the existing social networks consolidated due to poor public institutions and services (Rose-Ackerman, 1999). Corruption usually seems to interfere with the decisions coming from the public officials and the statist regulations that usually generate incentives for a corrupt environment (MungiuPippidi and Dadašov, 2016). Still, the ordinary people's tendency to pay bribes is considered a way of reinforcing and perpetuating a corrupt system in societies (Tavits, 2005). The previous idea is valid. And this applies especially when citizens perceive the public administration as ineffective and improper (De Sousa, 2008). 
From another perspective, Manzetti and Wilson (2007) stressed that when a corrupt government is elected and supported by the voters who benefit from its capacity to distribute public goods, they manifest high tolerance for the public institutions, thus perpetuating inefficient institutions that stimulate poverty and inequalities.

Another potential determinant of corruption relates to types of state involvement in the economy (e.g., fiscal and regulatory) (Bel, 2021). The consistent commitment in the economy means poor institutional functioning and tentacular bureaucracy (Galperin et al., 2020). Therefore, it incentivizes the desire for bribery payments (Malesky et al., 2015). The role of individual freedom as the main engine for progress in any society is considered potent concerning bribery propensity. We bear in mind the idea according to which those who think about this role given to liberty have at least the mental possibility to get involved in interactions generating such decisions, being aware of them. Another significant influence towards bribery propensity may play the level of interpersonal trust. A high trust level in most people is highly corrosive to the perception of corruption (Banerjee, 2016; Seligson, 2002).

To the best of our knowledge, parental religiosity is a variable not considered regarding the prediction of bribery behaviour. We have selected this predictor for analysis because parental role models may have a decisive effect on children's behaviour and attitude towards morality and lawfulness (Di Stefano, 2016). Furthermore, we consider that altruism may generate (un)conscious effects with the potential to increase the well-being of others in the absence of efficient institutions that stimulated an individual to behave unethically. Gneezy et al. (2014) demonstrate that the higher the levels of altruism, the lesser the levels of cheating, therefore altruism attenuated the negative effect of such behaviour. Gino et al. (2013) emphasize that individuals are more predisposed to behave unethically if this behaviour generates benefits for others. Hence, such a lack of ethics seems acceptable. Moreover, MuñozIzquierdo et al. (2014, p. 4) conclude that the results suggest that, when altruism is made salient, individuals pay attention to their moral standards and their self-concepts, decreasing their tendencies to engage in dishonest actions.

The feeling of responsibility is another predictor of bribery intention we took into consideration. We have considered it because the literature stated that the sense of responsibility, together with the powerful locus of control, are inimical to unethical conduct (Reckers and Samuelson, 2016). Moreover, it seemed correlated with feelings of guilt (Abraham and Pane, 2014). The latter is also responsible for attenuating the desire to act in an immoral way (Tangney et al., 2007).

The role of hard work to curb corrupt behaviours is also here. As considered by other scholars, hard work is an essential input. It brings success, along with others (efforts and skills). It positions itself on the opposite side with corrupt activities and attitudes (Amini and Douarin, 2020).

The large number of items initially taken into consideration relates to significant elements. These have the potential to influence the decision to be engaged in bribery. Therefore, we took into account in this study most of the ideas above. 
In the light of all these ideas, we started from the following hypotheses:

$\mathrm{H} 1$ : A behaviour that indicates taking advantage of undue benefits, favouritism, tax evasion, including not paying for public services, and buying stolen goods (a crime in mature countries such as the United Kingdom3) also indicates a high chance of bribe acceptance.

$\mathrm{H} 2$ : The level of etatism is a potent predictor of the intention of bribe payment.

$\mathrm{H} 3$ : The role of individual commitment to free competition and interpersonal trust influences the intention towards bribe payments.

H4: The traits inherited from parents, such as altruism, responsibility, and work ethics, could be considered inhibitors of potential corrupt behaviour.

\section{Data and methods}

This article is based on survey data conducted during the academic year 20172018 among 5072 students in economics from five Romanian universities: Alexandru Ioan Cuza University of Iasi (UAIC), "Babes-Bolyai” University of ClujNapoca (UBB); "Lucian Blaga" University of Sibiu (ULBS); "Stefan cel Mare" University of Suceava (USV); Academy of Economic Studies from Bucharest (ASE), and two from the Republic of Moldova, namely the Academy of Economic Studies of Moldova from Chișinău (ASEM) and "Alecu Russo" State University from Bălți (USB). The original purpose of the survey was to explore and explain the subjective mentalities, attitudes, and preferences of the Romanian and Moldavian students in economics towards becoming entrepreneurs, migrating to Western Europe, and bribery.

Choosing this type of students has nothing to do with convenience sampling, but we were fully aware that this category is more likely to behave in a self-interested way than others (Frank and Schulze, 2000), being, therefore, more tempted by potential corrupt behaviours. Because the sampling technique mostly relied on the authors' judgment when choosing who to ask to participate, it can be considered more as a judgment / purposive sampling. Still, given the dual nature (both social and economic) of the phenomenon under analysis, an important criterion for constructing the sample relied on the idea of randomly including students enrolled in various economics modules, from both undergraduate and master programmes. These students were enrolled in five major Romanian universities and two Moldavian ones, coming from different locations, with various standards of living, as detailed at the beginning of the section dedicated to results and discussions.

The questionnaire was distributed in printed format and completed face-toface at the beginning or end of courses/seminars/labs. And this because of the need

\footnotetext{
${ }^{3}$ U.S. Department of Justice, Office of Community Oriented Policing Services, Stolen Goods Markets, https://www.hsdl.org/?view\&did=682653 or https://www.ojp.gov/ncjrs/virtuallibrary/abstracts/stolen-goods-markets.
} 
for supervision and better control of the quality of responses. To ensure the anonymity of respondents, we did not collect any personal identification data, such as names or contact information. After collecting the completed questionnaires in physical format, the data was introduced by using Google Sheets. The most important questions included in the survey have been selected after previous documentation relating to the structure of the World Values Survey ${ }^{4}$.

The main goal is not just to present a set of variables that may stimulate or not the attitudes towards bribe payments, based on geographical or historical background, but to understand the reasons why these individuals consider bribery justifiable in certain conditions. Also, the article focuses on the differences in the perception of bribe payments across three groups of students from Romania and the Republic of Moldova. These two countries share the same language and culture, but their trajectory in the last almost two hundred years was different. Romania is a member of the European Union (EU) and North Atlantic Treaty Organization (NATO) and a capitalist country de facto. The Republic of Moldova still has a strong communist imprint in the economy and society and seeks a sustainable identity.

RM is still divided between the desire to integrate into the Western capitalist institutions and the proximity to the Russian paradigm. We believe that this status quo influences the mentalities, attitudes, and preferences regarding the attitude towards bribe payments.

The questionnaire was conducted exclusively in Romanian, with no linguistic and conceptual ambiguities, since we have additionally conducted pretest analysis. Also, when we have translated every question (Table A, Appendix) into English, formulations did not generate any confusion since the original one was clear enough.

For cleaning the data and making all the necessary derivations, we have used spreadsheet filters, including the ones on the coordinates to the respondents' permanent residences. The missing values for some questionnaire items, especially for those with an associated scale, have been treated as DK//NA (Do not know / No answer) and assimilated to the middle of the scale. In the case of RM, the questionnaire item related to the income and the corresponding options (7-point Likert scale) have been adapted to the local currency (Moldavian Leu vs. Romanian Leu- almost a $1 / 4$ ratio according to the exchange rate at that moment). Later, after collecting all responses, currency differences no longer created compatibility issues. In the case of variables corresponding to education (e.g. parents' education), because of the differences between the education systems of the two countries, we only considered the number of years of total schooling. In terms of respondents' grades (and the average of grades), there were no differences between Romania and RM.

The geographical distribution of responses was represented by using the Google Fusion Tables (GFT). Using this online tool, we generated an online query-

4 World Values Survey data, retrieved from https://www.worldvaluessurvey.org/ WVSContents.jsp - Data and Documentation section. 
able and highly interactive map with pushpins for different locations corresponding to the permanent residence of respondents.

To identify the common and most powerful influences of all the independent variables considered in this study (Table 1), we tested using the data mining add-in in Microsoft Excel (the classification algorithm based on the Naive Bayes technique) on the entire dataset (5072 responses), a subset corresponding to Romania (3999) and three others for the Republic of Moldova (RM, as the eastern neighbour of Romania today: 1073), SE-RO (or Southern and Eastern Romania, once former Kingdom of Romania - KR: 2137) and CW-RO (or Central-Western Romania, once occupied by the former Habsburg Empire-HE and consisting in Transylvania, Crișana, Maramureș, Banat and North-Western Bucovina: 1862). The results of using this add-in were persistent and query-able DM models in SQL Server Analysis Services (SSAS).

To estimate the respondents' propensity to pay bribes and assess the most important influences for testing the validity of all formulated hypotheses, we used a general econometric model, namely the one based on logit regressions (eq.1).

$$
\operatorname{Logit}(\mathrm{p})=\ln \left(\frac{\mathrm{p}}{1-\mathrm{p}}\right)=\beta_{0}+\sum_{\mathrm{j}=1}^{\mathrm{m}} \beta_{\mathrm{j}} * \mathrm{X}_{\mathrm{j}}+\varepsilon,
$$

Where: $\mathrm{p}$ is the probability of the intention to pay bribes; $\mathrm{Xj}$ - the independent variables (Tables 1 and 2 ), with $\mathrm{j}=1,2 \ldots \mathrm{m} ; \beta \mathrm{j}$ - the logit coefficients for each category of the dependent variable (Tables 1 and 2), and $\varepsilon$ is the error.

To correct for any form of heteroskedasticity, robust standard errors have been calculated. Moreover, a hierarchical approach with successive models, each adding more predictors, was considered for performing robustness checks (Tables 3-5, and A1-A3, Appendix).

To avoid multicollinearity, we reported the maximum absolute values of the correlation coefficients (Mukaka, 2012) in the predictors' matrices $(<0.25$ for all three most comprehensive regional models). Additionally, we performed Ordinary Least Square (OLS) regressions (Tables A1-A3, Appendix) and reported the maximum computed VIF (Variance Inflation Factor) against the maximum accepted one (1 / (1-overall models’ $\left.\mathrm{R}^{\wedge} 2\right)$ ). A VIF greater than this limit indicates (Vatcheva et al., 2016) that the correlation between the predictors is stronger than the regression relationship, and multi-collinearity can affect their coefficient estimates (Freund and Wilson, 1998).

To compare the influences inside and across models in terms of magnitude, we have used two methods. The first one is based on computing and reporting the average marginal effects. The second one is more visually oriented and consisted of generating logit-based probability prediction nomograms (Zlotnik and Abraira, 2015). 
Table 1. Descriptive statistics for the three subsets of respondents corresponding to CW-RO, SE-RO, and RM

\begin{tabular}{|c|c|c|c|c|c|c|c|c|c|c|c|c|c|c|c|c|c|c|}
\hline Subsets & Max nu & mber of & obs. fc & or $\mathrm{CW}$ & -RO: 1 & 1,862 & Max nu & mber of & obs. f & for $\mathrm{SE}$ - & -RO: 2 & 2,137 & Max $n$ & number & of obs & s. for $\mathrm{R}$ & RM: 1,0 & 073 \\
\hline & & & Std. & & & Yes & & & Std. & & & Yes & & & Std. & & & Yes \\
\hline Variables & Median & Mean & Dev. & Min & Max & 1) $\%$ & Median & Mean & Dev. & Min & Max & 1) $\%$ & Median & Mean & Dev. & Min & Max & (1) $\%$ \\
\hline inherited_hard_work & & & & & & 62 & & & & & & 61 & & & & & & 66 \\
\hline inherited_good_manners & & & & & & 89 & & & & & & 90 & & & & & & 85 \\
\hline inherited_independence & & & & & & 60 & & & & & & 55 & & & & & & 59 \\
\hline inherited_sense_responsibility & & & & & & 83 & & & & & & 83 & & & & & & 83 \\
\hline inherited_tolerance & & & & & & 74 & & & & & & 72 & & & & & & 73 \\
\hline inherited_perseverance & & & & & & 65 & & & & & & 65 & & & & & & 51 \\
\hline inherited_obedience & & & & & & 11 & & & & & & 7.9 & & & & & & 12 \\
\hline inherited_creativity_imagination & & & & & & 44 & & & & & & 39 & & & & & & 51 \\
\hline inherited_altruism & & & & & & 40 & & & & & & 36 & & & & & & 27 \\
\hline inherited_respect4elders & & & & & & 65 & & & & & & 65 & & & & & & 71 \\
\hline inherited_respect 4 traditions & & & & & & 43 & & & & & & 39 & & & & & & 55 \\
\hline clear_lasting_inherited_values & & & & & & 48 & & & & & & 46 & & & & & & 45 \\
\hline number_siblings & 1.00 & 1.12 & 1.35 & 0.00 & 9.00 & & 1.00 & 1.09 & 1.11 & 0.00 & 9.00 & & 1.00 & 1.25 & 1.10 & 0.00 & 9.00 & \\
\hline income_level & 4.00 & 3.85 & 1.86 & 1.00 & 7.00 & & 3.00 & 3.59 & 1.91 & 1.00 & 7.00 & & 3.00 & 2.79 & 1.33 & 1.00 & 7.00 & \\
\hline mother_education & 12.00 & 13.07 & 2.97 & 4.00 & 22.00 & & 12.00 & 12.87 & 2.87 & 8.00 & 22.00 & & 12.00 & 13.14 & 3.64 & 8.00 & 22.00 & \\
\hline father_education & 12.00 & 12.68 & 2.81 & 4.00 & 22.00 & & 12.00 & 12.70 & 2.77 & 8.00 & 22.00 & & 12.00 & 12.89 & 3.60 & 8.00 & 22.00 & \\
\hline both_parents_private_sector & & & & & & 46 & & & & & & 48 & & & & & & 39 \\
\hline only_mother_private_sector & & & & & & 8.8 & & & & & & 9.2 & & & & & & 8.8 \\
\hline only_father_private_sector & & & & & & 18 & & & & & & 21 & & & & & & 23 \\
\hline both_parents_faith_God & & & & & & 55 & & & & & & 45 & & & & & & 47 \\
\hline only_mother_faith_God & & & & & & 27 & & & & & & 32 & & & & & & 29 \\
\hline only_father_faith_God & & & & & & 2.9 & & & & & & 3 & & & & & & 4.1 \\
\hline both_parents_gone_abroad & & & & & & 11 & & & & & & 9.7 & & & & & & 15 \\
\hline only_mother_gone_abroad & & & & & & 5.6 & & & & & & 7.7 & & & & & & 10 \\
\hline only_father_gone_abroad & & & & & & 16 & & & & & & 18 & & & & & & 22 \\
\hline parental_severity & 7.00 & 6.31 & 2.33 & 1.00 & 10.00 & & 6.00 & 6.11 & 2.27 & 1.00 & 10.00 & & 7.00 & 6.43 & 2.35 & 1.00 & 10.00 & \\
\hline urban & & & & & & 70 & & & & & & 66 & & & & & & 74 \\
\hline Ro & & & & & & 100 & & & & & & 100 & & & & & & 0 \\
\hline fHEt & & & & & & 100 & & & & & & 0 & & & & & & 0 \\
\hline MoldInRo & & & & & & 0 & & & & & & 0 & & & & & & 15.10 \\
\hline male & & & & & & 31 & & & & & & 29 & & & & & & 26 \\
\hline
\end{tabular}




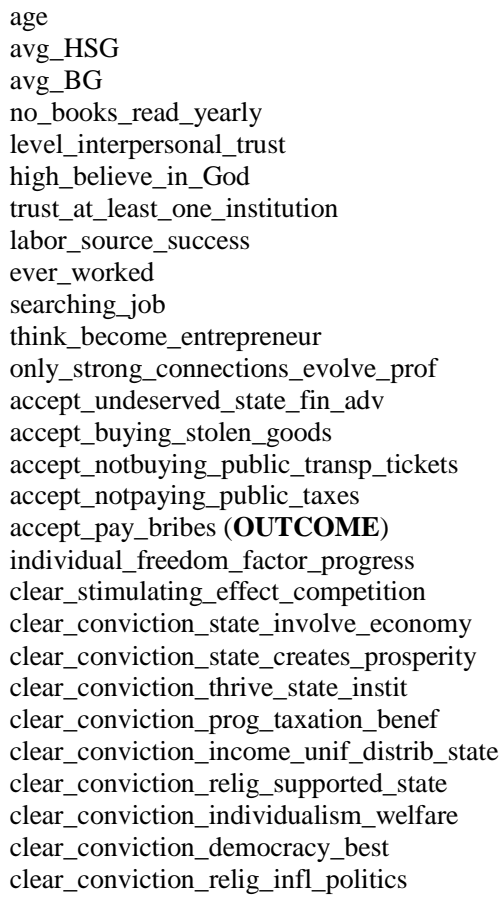

Source: Authors' calculations in Stata 16 MultiProcessing (MP).
$20.00 \quad 20.48 \quad 2.41 \quad 18.0047 .00$ $\begin{array}{lllll}9.15 & 9.04 & 0.63 & 5.10 & 10.00\end{array}$

$\begin{array}{llllll}8.70 & 8.54 & 0.89 & 5.50 & 10.00\end{array}$

$\begin{array}{lllll}2.00 & 2.46 & 1.00 & 1.00 & 6.00\end{array}$

$\begin{array}{lllll}2.00 & 2.44 & 0.87 & 1.00 & 5.00\end{array}$

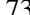

$\begin{array}{lllll}20.00 & 20.46 & 2.18 & 17.00 & 43.00\end{array}$

$\begin{array}{lllll}8.83 & 8.73 & 0.76 & 5.80 & 10.00\end{array}$

$\begin{array}{llllll}7.75 & 7.60 & 0.86 & 5.00 & 10.00\end{array}$

$\begin{array}{llllr}2.00 & 2.57 & 1.04 & 1.00 & 6.00\end{array}$

$\begin{array}{lllll}2.00 & 2.42 & 0.88 & 1.00 & 5.00\end{array}$

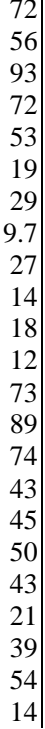

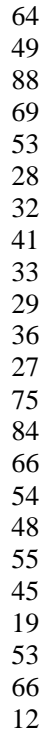


We identified common and particular influences by applying different procedures of variables selection in Stata 16. Next, we have decided to check if their common part passes or not the robustness checks along with many scenarios for each of those three specific areas (CW-RO, SE-RO, and RM) using logit regressions.

\section{Results and discussions}

This section presents the obtained results after performing logit regressions starting from the selected set of variables, with the indication of all significant influences.

The geographical distribution of responses as a query-able pushpin map of coordinates in GFT corresponding to respondents' location of origin was made starting from all 5072 records (Figure A-O1, Online Appendix). The Rows 1 button in GFT was used to create an online interactive representation of all respondents' residencies ( $\mathrm{H}$ for $\mathrm{CW}-\mathrm{RO}$; * for $\mathrm{SE}-\mathrm{RO}$ and $\mathrm{R}$ for $\mathrm{RM}$ ) which ensured access to the source data and basic support for replication of results (Figure A-O1, Online Appendix).

Considering the idea above, we have provided the results (top five influences) after performing 10 data mining tests (Figure A-O4, Online Appendix) in SSAS using the Naive Bayes algorithm trained on $75 \%$ and $100 \%$ of the entire dataset, the one for Romania, and those three for the aforementioned regions. Their common part (three influences corresponding to accept buying stolen goods, accept undeserved state financial advantages, the clear stimulating effect of competition) obtained in SSAS and the same results when using the cross validation-based LASSO (Tibshirani, 1996) variable selection procedure in Stata 16 led us to the idea of a triad of influences at the core of all regional models considered.

When considering an additional variable (fHEt) derived using a custom spreadsheet function named dot_in_poly, the latter (function design inside a .xlsm file - Figures A-O2 and A-O3, Online Appendix) was used to check the belonging (Yes: 1 meaning CW-RO, No: 0 meaning SE-RO or RM) of each respondent location to the interior of a polygon corresponding to that part of Romania once under the occupation of the former Habsburg Empire. When used for performing logit regressions on the overall dataset (all 5072 records), this split variable proved to be able to exert a significant negative influence, suggesting also that this geographical separation is important in terms of bribery. To be more explicit, belonging to $\mathrm{CW}$ $\mathrm{RO}(\mathrm{Ro}=1$ and $\mathrm{fHEt}=1)$ as an indication of belonging to western values and mentalities inhibits the behaviour of bribery when compared with the other two regions, namely $\mathrm{SE}-\mathrm{RO}(\mathrm{Ro}=1$ and $\mathrm{fHEt}=0)$ and $\mathrm{RM}(\mathrm{Ro}=0$ and $\mathrm{fHEt}=0)$. This was another reason to consider only the three corresponding subsets for regression analyses when controlling for individual, inherited and background characteristics.

The results of the regressions are presented below. The variable accept_notbuying_public_transp_tickets (a particular form of avoiding fees for 
public transportation) was found responsible for collinearity (the Max OLS computed VIF overpassed the Max OLS acceptable VIF if including it) when included together with accept_notpaying_public_taxes (accept not to pay public taxes/fees). The latter proved to be more powerful in terms of marginal effects and resulting accuracy. Therefore, accept_notbuying_public_transp_tickets has been removed from the models although the Data Mining algorithm using the Naïve Bayes technique (relying on the hypothesis of predictors' independence) suggested it. We believe that the individuals who have their permanent residences in cities and villages from CW-RO (Table 2 and Figure 1), possibly due to a historical imprint which still plays an important role in the trust in local public institutions (Becker et al., 2016) and to their exposure to local opportunities and incentives, are less inclined towards bribe payments, even as a mere intention.

Figure 1. Nomogram for assessing the bribery risk - respondents from CW-RO

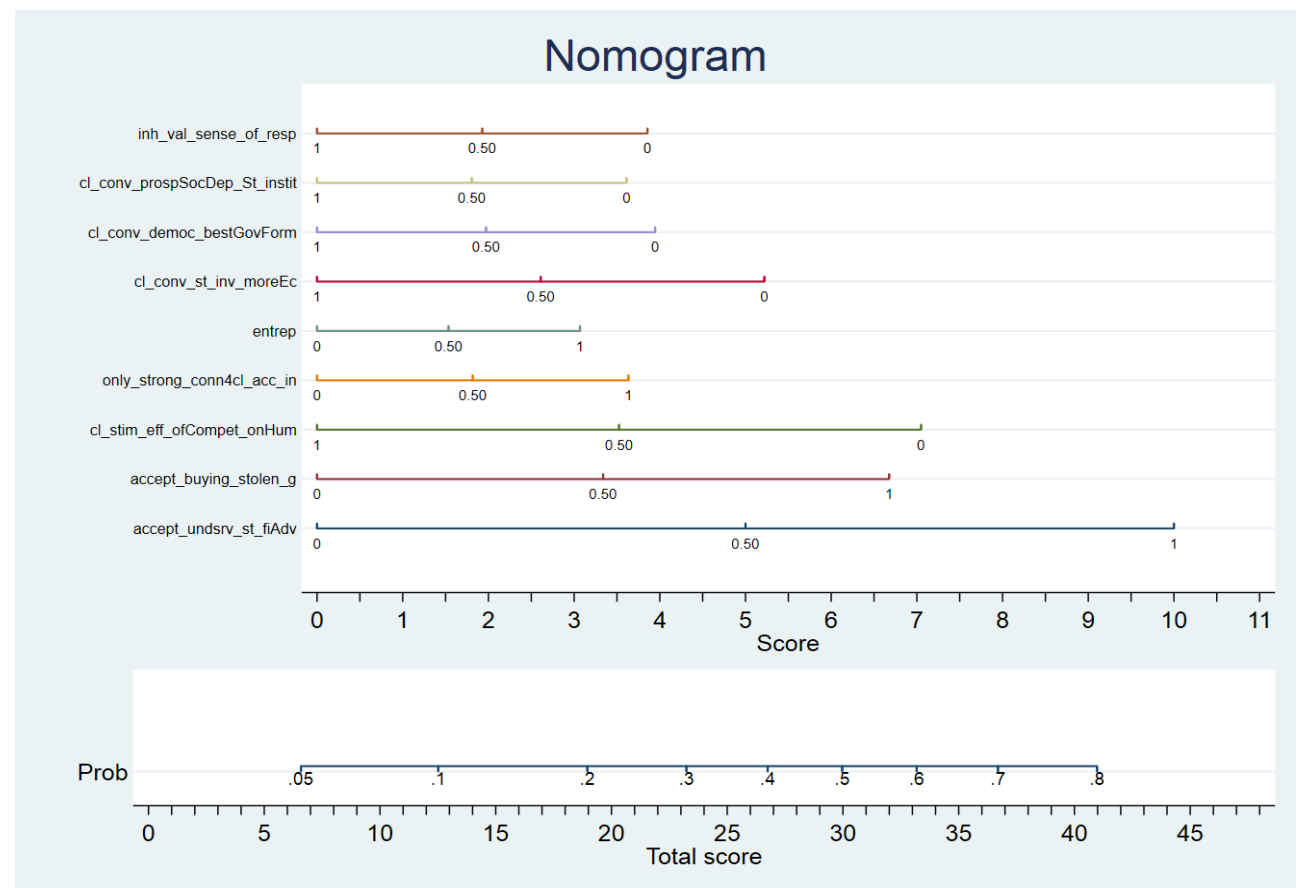

Source: Authors' representation 


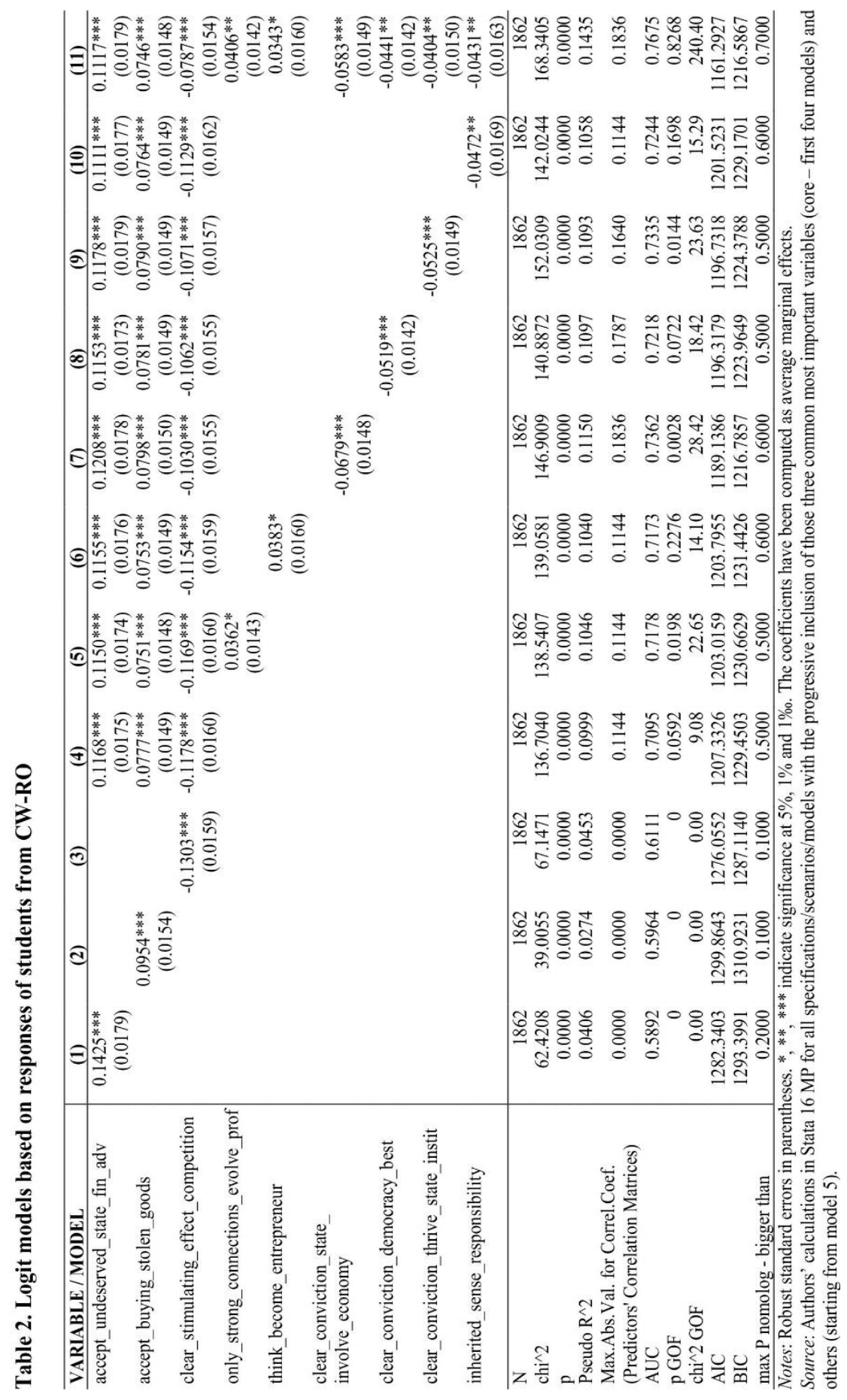


The positive influences (Table 2 and Figure 1) are given by several variables. The most powerful is favouritism, while the second magnitude comes from the possibility to buy stolen goods if cheaper than on the market. Also, the idea that the intention to become an entrepreneur after graduation and the opinion that only through nepotism or by pulling strings could someone have a successful career in the origin country are other positive predictors of the attitude towards bribe payments. The idea of a positive relationship between favouritism and bribery is validated by previous research, such as the Global Corruption Barometer ${ }^{1}$ in which individuals who consider that their local public services are mostly corrupt are determined to pay a bribe. To be more specific, from those interviewed from the Republic of Moldova, 40 to $50 \%$ said they paid a bribe, while 20 to $30 \%$ in the case of Romanians.

The positive influence exerted by the desire to become an entrepreneur on the bribe phenomenon may be explained as it follows: a highly restrictive regulatory environment, also supported by poor legal and economic institutions, increases the likelihood of business students to paying bribes to overcome bureaucratic barriers in their intention to set up a start-up business (Heuer and Liñán, 2013).

The strongest influence against the desire to pay bribes (a negative influence) is exerted by the conviction that competition makes people more diligent, productive, and innovative. The result emphasizes the fact that those individuals who put a great emphasis on the positive role of competition for interpersonal progress are eager to benefit from this status quo. Moreover, this meritocratic and competitive environment manifests as an important trigger to isolate and reduce the need to be engaged in corrupt behaviours. Moreover, other negative influences are exerted by the following ideas: the state should intervene more in the economy, democracy is the best form of government of a human community, a society is prosperous if institutions are governed by the state and the sense of responsibility, as a value inherited from parents, is important in life. The negative influence of a more interventionist role of the state in the economy on bribery is in line with other previous findings, such as Tanzi's (1994). This author emphasized that the more the state is involved in society, the more resources will be hijacked for bribery and undue benefits for political clients. The negative impact of the conviction about democracy which reduces the temptation of bribes is in line with previous studies (MacDonald and Majeed, 2011). It is considered that the older the democracy, the stronger the fight against the phenomenon of corruption (Beck et al., 2001).

The negative influence of the conviction regarding the proactive role of the state in the economy on bribe is in contradiction with other previous findings, in

1 Global Corruption Barometer (2017), Transparency International (retrieved from https://www.transparency.org/whatwedo/publication/people_and_corruption_citizens_voice s_from_around_the_world). 
which it was demonstrated that inefficient public bureaucracies generally create more bureaucratic obstacles to extract new bribe payments (Bertrand et al., 2007). Our latter negative finding is in line with other previous research which emphasizes that the sense of responsibility mediates the stimulating effect of collectivism towards the phenomenon of bribery (Mazar and Aggarwal, 2011). The result envisages the fact that the individuals who internalized the inherited quality of responsibility are less predisposed to pay bribes in certain situations, acting as moral actors who assume their professional and social duties and obligations in rational and legal ways.

Figure 2. Nomogram for assessing the bribery risk - respondents from SE-RO

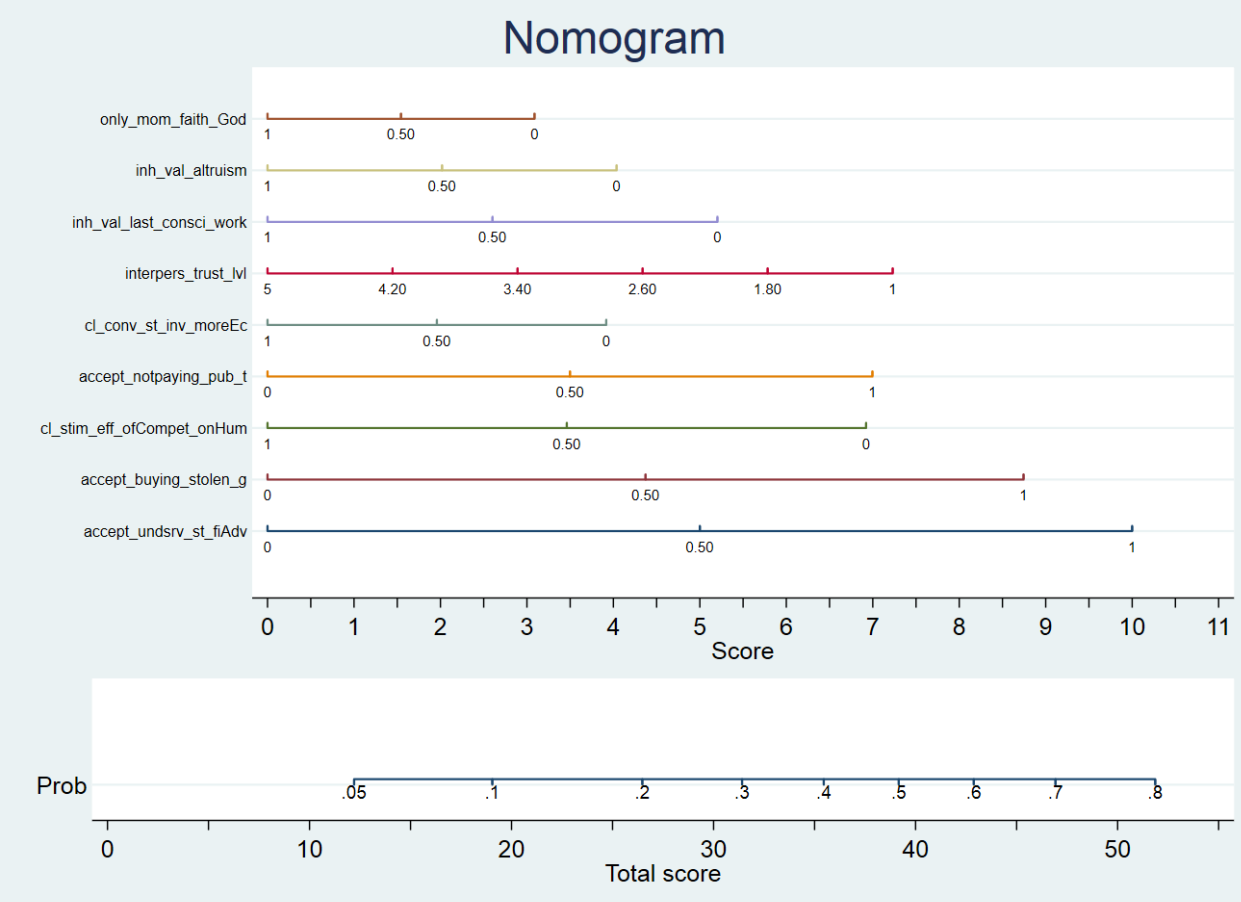

Source: Authors' representation

The preference to receive undeserved financial benefits from the state (Table 3 and Figure 2), the willingness to purchase stolen goods, and the choice to evade tax payments are positive predictors for the opportunity to pay bribes.

Six negative influences are illustrated in Table 3: the convictions that competition makes people more diligent, productive, and innovative, that the state should intervene more in the economy, altruism and hard work, as inherited values from parents, are important in life. Also, the higher the interpersonal trust, the lesser 
the propensity to pay bribes. This last finding is consistent with another previous research (Rothstein, 2000), stating that an individual with high levels of trust in other people is less oriented towards paying bribes.

The explanation lies in the fact that when interpersonal trust is high enough, transaction costs diminish, informal institutions work properly, and the propensity to be involved in corrupt behaviours fades. The negative influence of altruism on bribery is also consistent with other articles, such as Muñoz-Izquierdo et al. (2014). The result could be explained in the following way. Altruistic citizens penalize corrupt behaviours because they are prepared to act in society morally, according to their inherited beliefs.

Hard and rigorous work is strongly connected with a low level of corruption, as pointed by Balogun (2003) and Anttiroiko (2014). The result stresses that individuals who admitted that they have inherited a high appetence towards hard and conscientious work, who are diligent and put a great emphasis on work ethic are at antipodes compared with those whose ordinary behaviour tends towards looking for the easy way, without work, sacrifice and effort, therefore having no rebukes of conscience paying bribes to achieve their petty purposes.

Quite particular, the only external influence (also negative) is exerted by the mothers' level of religiosity, i.e. those students who have religious mothers are more likely to prefer to avoid receiving bribes in different daily situations. This finding is in line with other previous studies that analyzed how parents transmit their religiousness to children and how religious households have a stimulating influence on children's empathy and sense of justice, the latter being even more punitive against bad habits (Decety et al., 2015). 


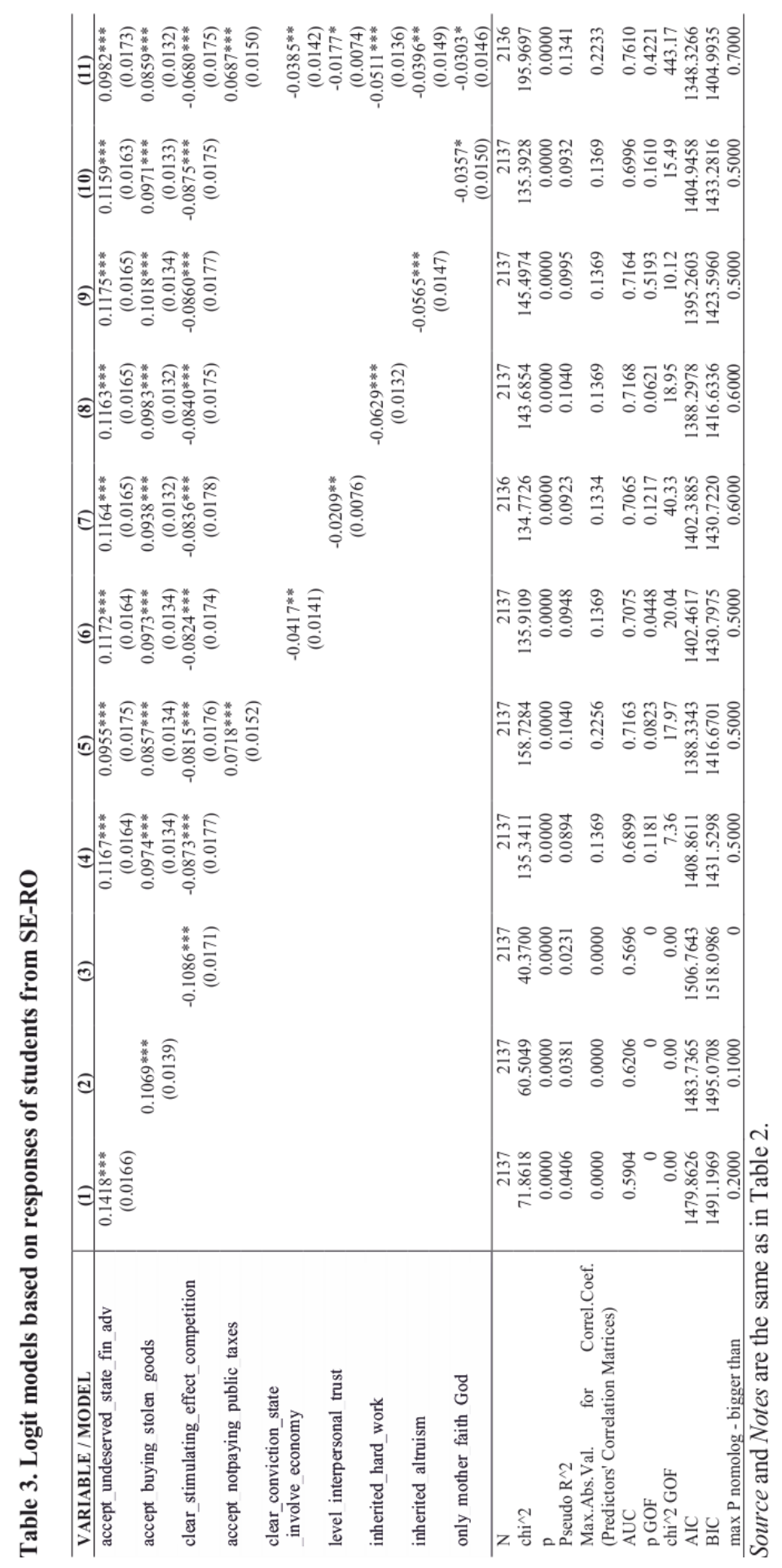




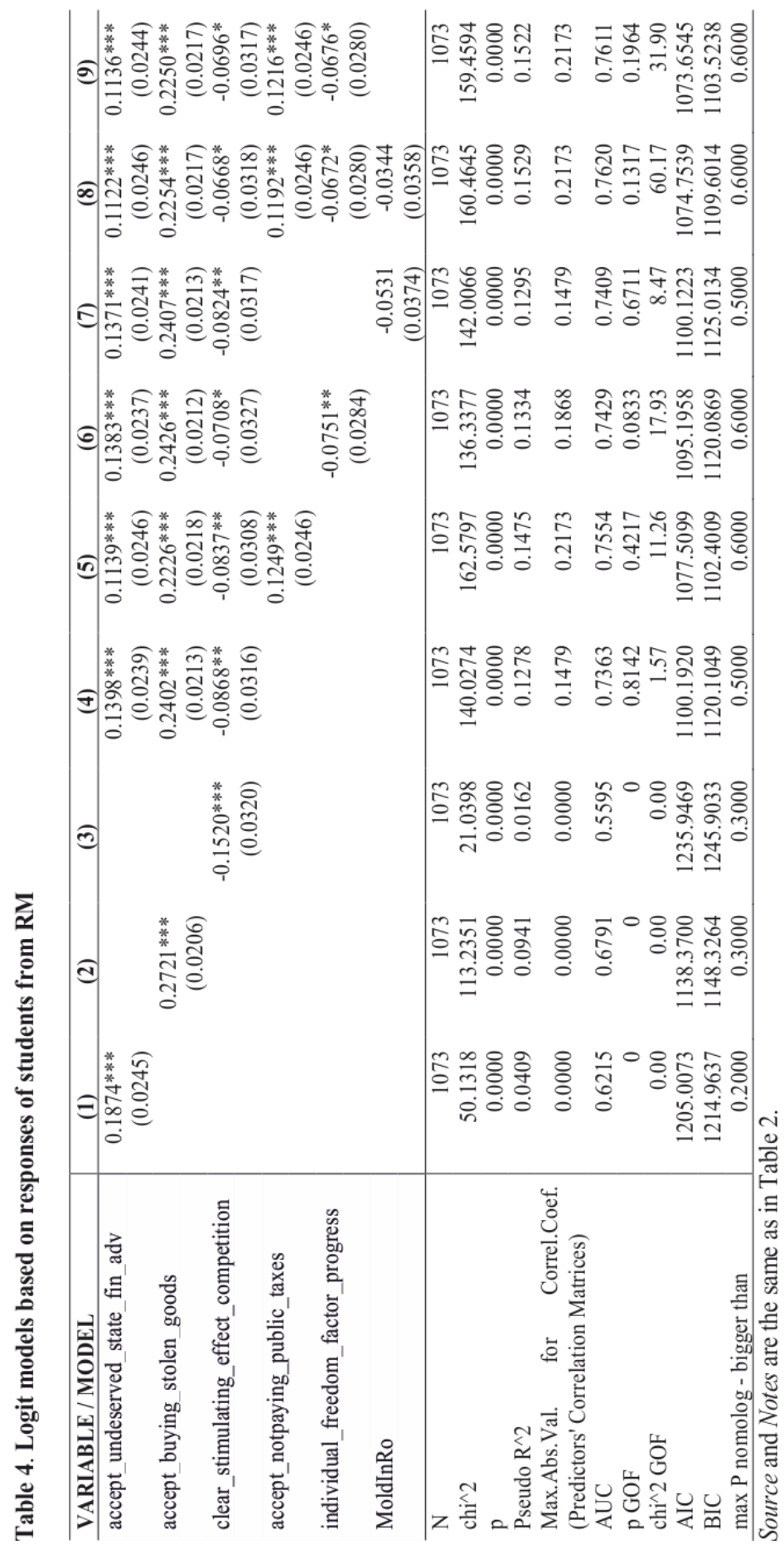


The model for the students in economics from both universities from the Republic of Moldova (Table 4 and Figure 3) brings lesser influences, some of them quite particular. The attitude towards bribe payments is positively influenced by the willingness to purchase stolen goods, the possibility to receive undeserved financial benefits from the state, the preference to evade tax payments. The results regarding the preference to evade tax payments emphasize that those who are more likely to cheat on taxes, therefore evading them, are more predisposed to pay bribes, being in line with other research studies (Buehn and Schneider, 2012). Such an idea underlines the predilection of tax evaders to be further engaged in illegal and immoral activities and attitudes involving bribery.

The only negative factor is exerted by the certainty that individual freedom is a certain cause of progress. Colombatto (2003) emphasized that corruption, including bribe actions, is perceived as unethical and is condemned only if the individuals are fully aware of their liberty in a free-based human community.

Additionally, when performing a T-test on the subset corresponding to RM, we did not find statistically significant differences (the significance level or Alpha of $1 \%$ was considered) in the means of the two subgroups obtained when using the variable indicating respondents from RM but studying at universities in Romania (MoldInRo). Moreover, the results in Table 4 and A3 (Appendix section) confirm the findings from the test above (lack of significance for MoldInRo) and the fact that the country of origin with its specificities seems to count more. And this also applies if we consider, by comparison, the T-test on the entire data set using the variable indicating Romania as a country of origin (Ro).

The latter suggests statistically significant differences (the same significance level above) in the means of the two subgroups depending on Ro. Similarly, the Ttest using the variable indicating the former belonging to territory once under the occupation of the long-gone Habsburg Empire (fHEt) for the subset corresponding only to respondents from Romania also suggests statistically significant differences (the same significance level above) in the means of the two subgroups depending on fHEt. Moreover, when considering these last two division variables, namely Ro and fHEt, separately in other two regressions on the overall dataset, with the same outcome related to bribery acceptance, the average marginal effects at means suggest a more powerful negative effect (almost twice as large) in the case of the first one (Ro). These differences are explainable in terms of the specific features of each region. For instance, if considering the development contrasts between Romania and Moldova (RM), and even between Central and Western (CW-RO) vs. Southern and Eastern (SE-RO) regions of Romania, the dilution of the inclination to accept bribes as we move away from the southeast and head northwest seems natural. Moreover, Romania is officially part of the European Union since 2007 and it is therefore aligned with the policy and desideratum of this union while Moldova (a former component of the Soviet Union between 1940 and 1991) is not yet there although we speak the same language and share millennia of common history. Therefore, the 
differences between CW-RO and SE-RO fade when compared with the ones between Romania and Moldova and this is also reflected in the phenomenon of corruption.

Figure 3. Nomogram for assessing the bribery risk - respondents from RM

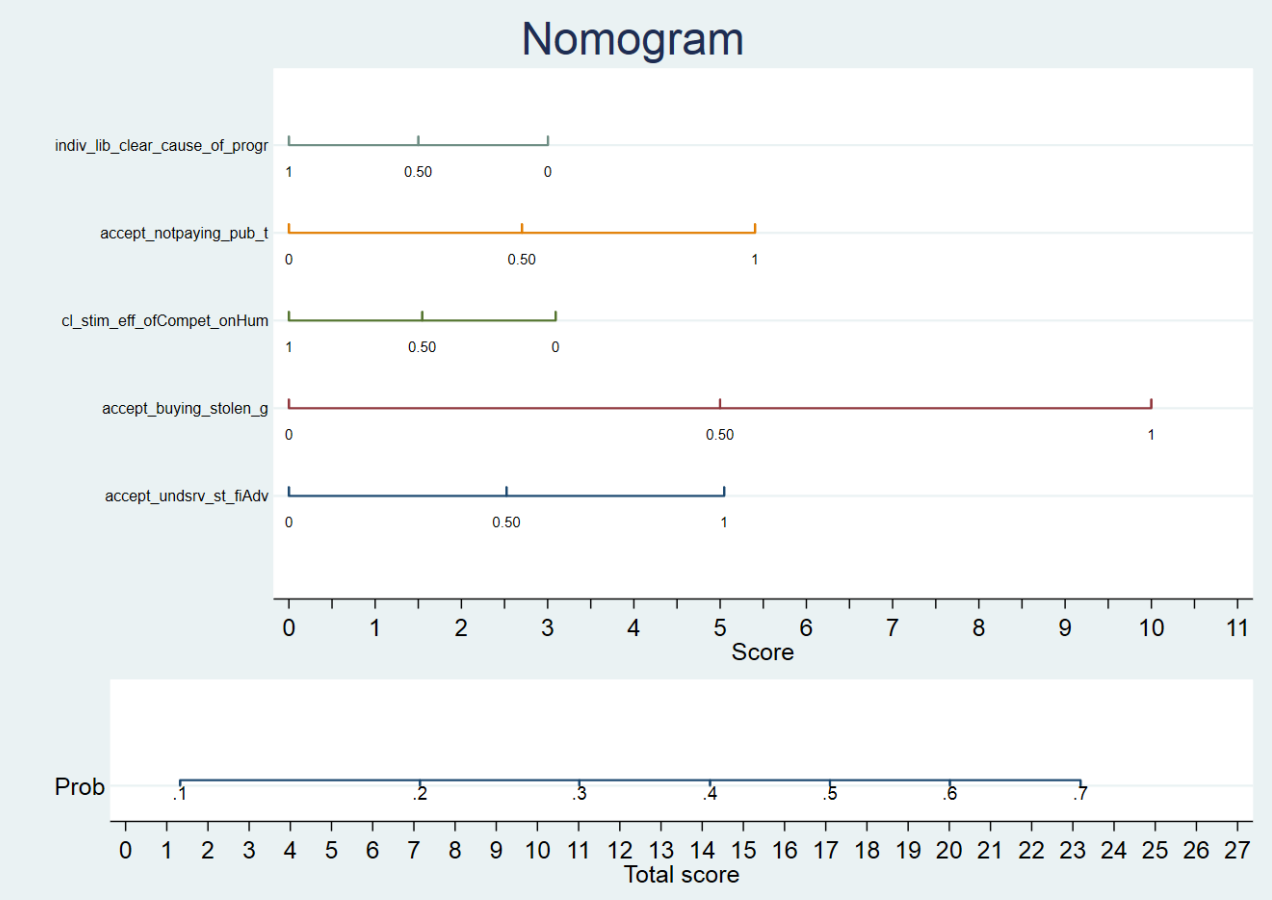

Source: Authors' representation

To sum up the individual scores for the influences in all three Zlotnik (2015) risk prediction nomograms above (Figures 1-3), we have drawn the perpendiculars (vertical dashed lines) to the score axis $(\mathrm{X})$ and we have found that:

- the influence corresponding to the ethical issue related to the acceptance of buying stolen goods is more pronounced in the Eastern region (RM);

- the influence corresponding to the positive role of competition on human actions is the strongest among the individuals from the Western region (CW-RO);

- the influence associated with the acceptance of undeserved public financial advantages (favouritism) is also the highest in the Western part (CW-RO).

As a result of the same aforementioned aggregations, we get totals representing maximum high risks of bribe payments (approximately $80 \%$ in Figure 1, $80 \%$ in Figure 2, and $70 \%$ in Figure 3), based on fair-to-good classifiers (ROC values between 0.76 and 0.77 in Tables 3 and 4 - model11, and in Table 4 - model 9) for all three historical regions. 
In terms of validation of hypotheses, $\mathrm{H} 1$ is confirmed by all three particular models, with the specification that for the students from CW-RO, only two variables are significant out of the total of the four considered. However, this validation is limited to young students in economics, because they are a particular category, being more adaptable and oriented towards extrinsic goals (Holland, 1985; Vansteenkiste et al., 2008). Hypothesis $\mathrm{H} 2$ is partially validated, entirely for CW-RO, partially for SE-RO, and not at all for RM. Hypothesis H3 is partially confirmed, the most appropriate model for this hypothesis being the one corresponding to SE-RO. Finally, H4 is not confirmed at all in the case of students from RM, partially for CWRO and fully for SE-RO.

When comparing these three subgroups, we additionally analyzed the marginal effects for different common influences. Consequently, we have found that the students from RM who accept the idea of buying stolen goods are more likely (more than 25 percentage points) to pay bribes than those who do not agree with this choice when the rest of the variables in the models have the least stimulating values for this phenomenon. Quite striking, in the case of the students whose residencies are inside CW-RO and SE-RO, these percentage points are below 5\%, with the same observation related to the rest of the variables, as pointed above. We have also found that the role of competition as a factor in human progress is different across subgroups. Hence, in CW-RO and SE-RO, the students put a smaller emphasis on competition than their counterparts from RM ( $6 \%$ and 3\%vs. more than $10 \%)$ with the same observation above. Still, for the latter, the significance is lower. If they agree to engage in tax evasion behaviour, the probability to intend to pay bribes differs for the students from RM when compared to those from SE-RO, revealing a difference of over $12 \%$ (more than $15 \%$ vs. $~ 3 \%$ ) with the same observation related to the rest of the variables, as mentioned above.

In terms of endogeneity (suspected for the variable accept_buying_stolen_goods), we started from evidence in the literature (Sheley and Bailey, 1985), where we found an early emphasis on morality (moral appeal) and income. Consequently, we considered the level of income (income_level), the belief in God of both respondent's parents (both_parents_faith_God), and a third variable indicating that the respondent considered the inherited values from parents significant and lasting (clear_lasting_inherited_values). We assumed all these three as instruments, while the one corresponding to acceptance of buying stolen goods as endogenous. Apart from these instrument variables for endogeneity, we included two additional independent predictors as part of the three common influences already identified, namely accept_undeserved_state_fin_adv and clear_stimulating effect_competition. Then we used both ivregress 2 sls and ivreg2 on the overall dataset. The results for three types of post estimations in the case of ivregress 2 sls indicated that the assumption above (suspicion of endogeneity) does not stand. The Durbin and Wu-Hausman tests of endogeneity (Davidson and MacKinnon, 1993) using estat endog in Stata have shown $\mathrm{p}$ values greater than $0.05(\mathrm{p}=0.0687$ for 
Durbin and $\mathrm{p}=0.0688$ for $\mathrm{Wu}$-Hausman). By that, they did not contradict the $\mathrm{H} 0$ hypothesis (here, the one that the tested variable is exogenous). An additional test called first-stage regression statistics (estat firststage in Stata) contradicted the H0 hypothesis. Here, H0 meant that instruments are weak - the Cragg-Donald (1993) Wald F statistic greater than all Stock-Yogo test critical values. The third test, namely Sargan (1958) and Basmann (1960) checked the overidentifying restrictions (estat overid in Stata). It generated large $\mathrm{p}$ values $(>0.2)$, which did not contradict the $\mathrm{H} 0$ hypothesis, namely the one that our instruments are valid and the model is correctly specified. We confirmed these results when using a similar command (ivreg2) with easier use.

\section{Conclusions}

The paper analyzes the predictors of bribe payments for three distinct regions delineated by former historical borders, namely the Central and Western parts of current Romania (coded as CW-RO), the Southern and Eastern parts (as SE-RO), and the Republic of Moldova (as RM). Using survey data from students in economics from seven Romanian and Moldavian universities, collected between 2017 and 2018, we have identified different particular patterns for the corresponding subsets. The results are not discussed in causal terms due to the peculiarities of bribe intentions and the statistical methods used (OLS and logit regressions with corresponding nomograms providing an intuitive way to assess the corresponding bribery risks for all three specific regions). Moreover, they are limited to the chosen type of respondents, namely young students in economics, a more adaptable and goaloriented category. This also means that, for punctual recommendations corresponding to other occupational profiles of respondents, we will need to reapply for this survey and perform additional tests.

In terms of theoretical contributions, to our knowledge, this research is the first one taking into account the split according to a long-gone historical border, therefore identifying specific influences on the propensity for bribe payments. Our results reveal interesting facts, amplifying the role of history and culture in explaining different behaviours. Moreover, they show that proximity to western and eastern civilizations counts for explaining consistent differences in the intensity of common influences as well as the nature of peculiar ones. Three main influences are common to all three regional models categories (from 4 to 11 or from 4 to 9 ), namely competition (negative sign and stronger for CW-RO), accepting undue advantages, and buying stolen goods (both positive and stronger for RM). Coupled with the fact that another influence corresponding to the permanent residence in the Republic of Moldova and studying in Romania (UAIC, UBB, ULBS, ASE, or USV) is not significant (RM models), this suggests the powerful roots of the Russian heritage in the case of RM. The latter also seems to be responsible for the communist imprint in the economy and society. The partially common influences, namely the tax evasion 
behaviour (positive influence and applying for both SE-RO and RM, being stronger for RM) and the attitude towards the interventionist role of the state in the economy (negative influence and corresponding to both $\mathrm{CW}-\mathrm{RO}$ and SE-RO, being stronger for CW-RO) suggest the same when it comes to the Russian heritage and also the powerful roots of the Habsburg heritage (for $\mathrm{CW}-\mathrm{RO}$ ). This conclusion also results when looking at the peculiarities of these three regional models categories. Therefore, in the case of students with residencies in CW-RO, the novelty is brought by the variable related to nepotism, which is underlined only in this model, students considering that such behaviour is motivating for bribe payments. This result is in line with Köbis et al. (2015), who demonstrated that perceived descriptive corruption norms in a society determine the propensity of an individual to engage in corrupt behaviour. Another particular feature is students' decision to become entrepreneurs after graduation, an idea that may indicate a positive prediction for corrupt behaviours. These two variables are in line with other previous research, hence our article emphasizes that students in economics residing in cities and villages inside CW-RO consider behaving in a corrupt way when public institutions are not meritocratic nor stimulating for engaging in free-market behaviours. The same subgroup of students is not willing to pay bribes when considering the active role of the state through its formal institutions in the economy when manifesting a democratic attitude and having responsibility as an inherited value.

The second group of students (SE-RO) discloses other ethical aspects, except for those that are part of the aforementioned triad (the incentive effect of competition and tax evasion behaviour), that accompany the decision for bribe payments. The attitude of not paying taxes is somehow related to a certain environment in which citizens are aware that the money collected by the state is distributed in a nontransparent way (Mungiu-Pippidi, 2017). The rest of the variables negatively influence such a potential decision. Therefore, those who put stress on the value of work ethic and altruism manifest low interpersonal trust, and those whose mothers are highly religious are then not inclined to accept the payment of bribes.

For the students from RM, there are several peculiarities. The first one is about the negative role played by the subjective value attributed to individual freedom as a factor of progress in society on the potential corrupt behaviour. The second one is quite striking and emphasizes less significance in the case of the third element of the common triad, namely the role of competition in stimulating individuals to be more diligent, productive, and/or innovative, compared to the previous two regional models. In this sense, it is obvious that the role of competition as a predictor of corrupt behaviour is much less important for this subgroup of students. This latter influence could be explained by the structural economic backwardness of RM compared to Romania. Thirdly, we have also identified two powerful stimulating variables related to tax evasion behaviours.

In terms of support actions, counter-measures, and stimulating or corrective policies, any decision-maker must continuously put a special emphasis on 
competition, honesty, transparency, as well as on national and regional identity. In addition, state institutions need to be strengthened when it comes to law enforcement, promotion of honesty, meritocracy, investment in infrastructure for public services, and increased potential to provide incentives for competition, private initiative, productivity, and growth.

Acknowledgements: We thank all the students who participated in this study and all the staff of the faculties involved who helped us distribute the questionnaire and collect the responses: Elisabeta Jaba (UAIC), Alin Adrian Mihaila (UBB), Renate Doina Bratu (ULBS), Ovidiu-Aurel Ghiuță (USV), Monica Mihaela Roman (ASE), Ion Profir Pârţachi (ASEM), and Nelu Florea (USB).

\section{References}

Abraham, J. and Pane, M.M. (2014), Corruptive tendencies, conscientiousness, and collectivism, Procedia - Social and Behavioral Sciences, 153, pp. 132-147.

Ajzen, I. (1985), From intentions to actions: a theory of planned behavior, in: Kuhl, J. and Beckmann, J. (eds.), Action control. SSSP Springer Series in Social Psychology, Berlin: Springer, pp. 11-39.

Ajzen, I. (1991), The theory of planned behavior, Organizational Behavior and Human Decision Processes, 50(2), pp. 179-211.

Amini, C. and Douarin, E. (2020), Corruption and life satisfaction in transition: is corruption a social norm in Eastern Europe?, Social Indicators Research, 151, pp. 723-766. https://doi.org/10.1007/s11205-020-02389-6

Banerjee, R. (2016), Corruption, norm violation and decay in social capital, Journal of Public Economics, 137, pp. 14-27. https://doi.org/10.1016/j.jpubeco.2016.03.007

Bank of Greece, Bulgarian National Bank, National Bank of Romania, Österreichische Nationalbank (2014), South-Eastern European Monetary and Economic Statistics from the Nineteenth Century to World War II, Athens, Sofia, Bucharest, Vienna, (retrieved from https://www.bankofgreece.gr/RelatedDocuments/SEEMHN\%20Data $\% 20$ Volume\%202014.pdf)

Barr, A. and Serra, D. (2010), Corruption and culture: an experimental analysis, Journal of Public Economics, 94(11-12), pp. 862-869. https://doi.org/10.1016/ j.jpubeco.2010.07.006

Basmann, R. (1960), On finite sample distributions of generalized classical linear identifiability test statistics, Journal of the American Statistical Association, 55(292), pp. 650-659.

Beck, T., Clarke, G., Groff, A., Keefer, P. and Walsh, P. (2001), New tools in comparative political economy: the database of political institutions, World Bank Economic Review, 15(1), pp. 169-217. 
Becker, S.O., Boeckh, K., Heinz, C. and Woessmann, L. (2016), The empire is dead, long live the empire! Long-run persistence of trust and corruption in the bureaucracy, The Economic Journal, 126(590), pp. 40-74. https://doi.org/10.1111/ecoj.12220

Bel, G. (2021), Beyond government size: Types of government intervention and corruption, Regulation \& Governance. https://doi.org/10.1111/rego.12399

Bertrand, M., Djankov, S., Hanna, R. and Mullainathan, S. (2005), Obtaining a driving license in India: an experimental approach to studying corruption, The Quarterly Journal of Economics, 122(4), pp. 1639-1676. https://doi.org/10.1162/qjec.2007.122.4.1639

Buehn, A. and Schneider, F. (2012), Corruption and the shadow economy: like oil and vinegar, like water and fire?, International Tax and Public Finance, 19(1), pp. 172194.

Č́belková, I. and Hanousek, J. (2004), The power of negative thinking: corruption, perception and willingness to bribe in Ukraine, Applied Economics, 36(4), pp. 383397.

Cameron, L., Chaudhuri, A., Erkal, N. and Gangadharan, L. (2015), Propensities to engage in and punish corrupt behavior: experimental evidence from Australia, India, Indonesia and Singapore, Journal of Public Economics, 93(7-8), pp. 843-851.

Colombatto, E. (2003), Why is corruption tolerated?, The Review of Austrian Economics, 16(4), pp. 363-379.

Cragg, J.G. and Donald, S.G. (1993), Testing identfiability and specification in instrumental variables models, Econometric Theory, 9, pp. 222-240.

Davidson, R. and MacKinnon, J.G. (1993), Estimation and Inference in Econometrics, New York: Oxford University Press.

De Jong, E. and Bogmans, C. (2011), Does corruption discourage international trade?, European Journal of Political Economy, 27(2), pp. 385-398. https://doi.org/10.1016/j.ejpoleco.2010.11.005

De Jong, G. and Van Ees, H. (2014), Firms and corruption, European Management Review, 11, pp. 187-190. https://doi.org/10.1111/emre.12036

De Sousa, L. (2008), I don't bribe, I just pull strings: assessing the fluidity of social representations of corruption in Portuguese society, Perspectives on European Politics and Society, 9(1), pp. 8-23.

Decety, J., Cowell, J.M., Lee, K., Mahasneh, R., Malcolm-Smith, S., Selcuk, B. and Zhou, X. (2015), The negative association between religiousness and children's altruism across the world, Current Biology, 25, pp. 2951-2955.

Di Stefano, P. (2016), Understanding rescuing during the Rwandan genocide, Peace Review, 28(2), pp. 195-202. https://doi.org/10.1080/10402659.2016.1166755

Drugov, M. (2010), Competition in bureaucracy and corruption, Journal of Development Economics, 92(2), pp. 107-114. https://doi.org/10.1016/j.jdeveco.2009.02.004 
Frank, B. and Schulze, G.G. (2000), Does economics make citizens corrupt?, Journal of Economic Behavior \& Organization, 43(1), pp. 101-113. https://doi.org/10.1016/S0167-2681(00)00111-6

Freund, R.J. and Wilson, W.J. (1998), Regression analysis: statistical modeling of a response variable, San Diego: Academic Press.

Galperin, B.L., Enueme, C.F. and Dixon, D.P. (2020), Pay the bribe or take the high road: dilemma of a young female Tanzanian entrepreneur, The CASE Journal, 16(1), pp. 75-96. https://doi.org/10.1108/TCJ-05-2018-0063

Georgieva, I. (2000), Using transparency against corruption in public procurement: a comparative analysis of the transparency rules and their failure to combat corruption, Cham: Springer.

Ghura, H., Harraf, A., Li, X. and Hamdan, A. (2019), The moderating effect of corruption on the relationship between formal institutions and entrepreneurial activity, Journal of Entrepreneurship in Emerging Economies, 12(1), pp. 58-78. https://doi.org/10.1108/JEEE-03-2019-0032

Gino, F., Shahar, A. and Ariely, D. (2013), Self-serving altruism? The lure of unethical actions that benefit others, Journal of Economic Behavior \& Organization, 93, pp. 285-292. https://doi.org/10.1016/j.jebo.2013.04.005

Gneezy, U., Imas, A. and Madarász, K. (2014), Conscience accounting: emotion dynamics and social behavior, Management Science, 60(11), pp. 2645-2658. https://doi.org/10.1287/mnsc.2014.1942

Gorsira, M., Denkers, A. and Huisman, W. (2016), Both sides of the coin: motives for corruption among public officials and business employees, Journal of Business Ethics, 151(1), pp. 1-16. https://doi.org/10.1007/s10551-016-3219-2

Hauk, E. and Saez-Marti, M. (2002), On the cultural transmission of corruption, Journal of Economic Theory, 107(2), pp. 311-335. https://doi.org/10.1006/jeth.2001.2956

Heidenheimer, A.J. (2005), Perspectives on the perception of corruption, in: Heidenheimer, A.J. and Johnston, M. (eds.), Political Corruption: Concepts and Contexts, New Brunswick: Transaction Publishers, pp. 141-154.

Heuer, A. and Liñán, F. (2013), Testing alternative measures of subjective norms in entrepreneurial intention models, International Journal of Entrepreneurship and Small Business, 19(1), pp. 35-50. https://doi.org/10.1504/IJESB.2013.054310

Holland, J.L. (1985), Making vocational choices: A theory of careers, Englewood Cliffs, NJ: Prentice-Hall.

Johnson, N.D., LaFountain, C. and Yamarik, S. (2013), Corruption is bad for growth (even in the United States), Public Choice, 147(3), pp. 377-393. https://doi.org/10.1007/s11127-010-9634-5

Jong-Sung, Y. and Khagram, S. (2005), A comparative study of inequality and corruption, American Sociological Review, 70(1), pp. 136-157. https://doi.org/10.1177/000312240507000107 
Ko, K. and Samajdar, A. (2010), Evaluation of international corruption indexes: should we believe them or not?, The Social Science Journal, 47(3), pp. 508-540. https://doi.org/10.1016/j.soscij.2010.03.001

Köbis, N.C., van Prooijen, F. J.-W., Righetti, F. and van Lange, P.A.M. (2015), "Who doesn't?"-The impact of descriptive norms on corruption, PLoS One, 10(6), p. e0131830.

Logue, N.C. (2005), Cultural relativism or ethical imperialism? Dealing with bribery across cultures, CBFA Conference, New York, USA (retrieved from http://citeseerx.ist.psu.edu/viewdoc/download;jsessionid=CF81AAB33AAC3DE1C 4E7EFAC13417852?doi=10.1.1.662.9233\&rep=rep1\&type=pdf).

Macdonald, R. and Majeed, M. (2019), Causes of corruption in European countries: history, law, and political stability (retrieved from https://www.gla.ac.uk/media/ media_218412_en.pdf).

Madden, T., Scholder, P.E. and Ajzen, I. (1992), A comparison of the theory of planned behavior and the theory of reasoned action, Personality and Social Psychology Bulletin, 18(1), pp. 3-9.

Malesky, E.J., Gueorguiev, D.D. and Jensen, N.M. (2015), Monopoly money: Foreign investment and bribery in Vietnam, a survey experiment, American Journal of Political Science, 59(2), pp. 419-439. https://doi.org/10.1111/ajps.12126

Manzetti, L. and Wilson, C.J. (2007), Why do corrupt governments maintain public support?, $\begin{array}{llll}\text { Comparative Political } & \text { Studies, } & \text { 40(8), } & \text { 949-970. }\end{array}$ https://doi.org/10.1177/0010414005285759

Markevich, A. (2019), A regional perspective on the economic development of the late Russian Empire (retrieved from https://ssrn.com/abstract=2555273).

Mazar, N. and Aggarwal, P. (2011), Greasing the palm: can collectivism promote bribery?, $\begin{array}{llll}\text { Psychological } & \text { Science, } & \text { 22(7), } & \text { 843-848. }\end{array}$ https://doi.org/10.1177/0956797611412389

Mishler, W. and Rose, R. (2001), What are the origins of political trust? Testing institutional and cultural theories in post-communist societies, Comparative Political Studies, 34(1), pp. 30-62. https://doi.org/10.1177/0010414001034001002

Mocan, N., Bielen, S. and Marneffe, W. (2020), Quality of judicial institutions, crimes, misdemeanors, and dishonesty, European Journal of Political Economy, 61, p. 101815. https://doi.org/10.1016/j.ejpoleco.2019.101815

Mukaka, M.M. (2012), A guide to appropriate use of correlation coefficient in medical research, Malawi Medical Journal, 24(3), pp. 69-71.

Mungiu-Pippidi, A. (2016), The Quest for Good Governance, Iași: Polirom.

Mungiu-Pippidi, A. and Dadašov, R. (2016), Measuring control of corruption by a new index of public integrity, European Journal on Criminal Policy and Research, 22(3), pp. 415-438. https://doi.org/10.1007/s10610-016-9324-Z 
Muñoz-Izquierdo, N., de Liano, B.G.-G., Rin-Sanchez, F.D. and Pascual-Ezama, D. (2014), Cheating and altruism by discipline, MPRA Paper, 89579 (retrieved from https://mpra.ub.uni-muenchen.de/89579/1/MPRA_paper_89579.pdf).

Nam, T. (2018), Examining the anti-corruption effect of e-government and the moderating effect of national culture: A cross-country study, Government Information Quarterly, 35(2), pp. 273-282. https://doi.org/10.1016/j.giq.2018.01.005

Ramamoorthy, N., Kulkarni, S. and Gupta, A. (2015), To bribe or not to bribe?, Determinants in the Indian context, European Management Review, 12(4), pp. 247-259. https://doi.org/10.1111/emre.12053

Reckers, P. and Samuelson, M. (2016), Toward resolving the debate surrounding slippery slope versus licensing behavior: the importance of individual differences in accounting ethical decision making, Advances in Accounting, 34, pp. 1-16. https://doi.org/10.1016/j.adiac.2016.07.003

Rodríguez-Pose, A. and Maslauskaite, K. (2012) Can policy make us happier? Individual characteristics, socio-economic factors and life satisfaction in Central and Eastern Europe, Cambridge Journal of Regions, Economy and Society, 5(1), pp. 77-96. https://doi.org/10.1093/cjres/rsr038

Rose-Ackerman, S. (1975), The economics of corruption, Journal of Public Economics, 4(2), pp. 187-203.

Rose-Ackerman, S. (1999), Corruption and Government Causes, Consequences and Reform, Cambridge: Cambridge University Press.

Ryvkin, D. and Serra, D. (2020), Corruption and competition among bureaucrats: An experimental study, Journal of Economic Behavior \& Organization, 175, pp. 439451. https://doi.org/10.1016/j.jebo.2017.12.026

Sargan, J. (1958), The estimation of economic relationships using instrumental variables, Econometrica, 26(3), pp. 393-415.

Schulze, M.S. (2007), Regional Income Dispersion and Market Potential in the Late Nineteenth Century Hapsburg Empire, Working Papers No. 106/07, Department of Economic History, London School of Economics, pp. 1-30.

SEEMHN (2014), South-Eastern European Monetary and Economic Statistics fromnthe Nineteenth Century to World War II, published by: Bank of Greece, Bulgarian National Bank, National Bank of Romania, Oesterreichische Nationalbank, Athens, Sofia, Bucharest, Vienna.

Seligson, M.A. (2002), The impact of corruption on regime legitimacy: a comparative study of four Latin American countries, The Journal of Politics, 64(2), pp. 408-433. https://doi.org/10.1111/1468-2508.00132

Sheley, J.F., Bailey, K.D. (1985), New directions for anti-theft policy: Reductions in stolen goods buyers, Journal of criminal justice, 13(5), pp. 399-415.

Shen, H., Wan, F. and Wyer, Jr., R.S. (2011), Cross-cultural differences in the refusal to accept a small gift: the differential influence of reciprocity norms on Asians and North Americans, Journal of Personality and Social Psychology, 100(2), pp. 271-281. https://doi.org/10.1037/a0021201 
Stahl, C., Kassa, S. and Baez-Camargo, C. (2017), Drivers of petty corruption and anticorruption interventions in the developing world - a semi-systematic review (retrieved fromhttps://baselgovernance.org/sites/default/files/2019-

01/earf_literature_review.pdf).

Tangney, J.P., Stuewig, J. and Mashek, D. J. (2007), Moral emotions and moral behavior, Annual Review of Psychology, 58, pp. 345-372. https://doi.org/10.1146/annurev.psych.56.091103.070145

Tanzi, V. (1994), Corruption, governmental activities, and markets, Working Paper 94/99, International Monetary Fund (retrieved from https://www.imf.org/en/Publications/ WP/Issues/2016/12/30/Corruption-Governmental-Activities-and-Markets-1912)

Tavits, M. (2005), Causes of corruption: testing competing hypotheses, Working Paper, (retrieved from https://www.nuffield.ox.ac.uk/politics/papers/2005/tavits\%20 nuffield\%20wp.pdf).

Tibshirani, R. (1996), Regression shrinkage and selection via the lasso, Journal of the Royal Statistical Society Series B Method, 58(1), pp. 267-288.

Transparency International (2017), Corruption Perception Index 2017, (retrieved from https://www.transparency.org/news/feature/corruption_perceptions_index_2017).

Transparency International (2017), What is corruption? (retrieved from https://www.transparency.org/what-iscorruption).

Transparency International (2018), Corruption Perception Index 2018, (retrieved from https://www.transparency.org/cpi2018, accessed December, 9th, 2018.

Tudor, A.T. and Matis, D. (2010), Options for a modern accounting system in 19(th) century Transylvania, Transylvanian Review, 19(1), pp. 47-59.

Uslaner, E.M. and Bădescu, G. (2004), Honesty, trust and the legal norms in the transition democracy: why Bo Rothstein is better able to explain Sweden than Romania, in: Kornai, R. and Rose-Ackerman, S. (eds.), Creating Social Trust in Post-Socialist Transition, New York: Palgrave Macmillan, pp. 31-52.

Vansteenkiste, M., Timmermans, T., Lens, W., Soenens, B. and Van den Broeck, A. (2008), Does extrinsic goal framing enhance extrinsic goal-oriented individuals' learning and performance? An experimental test of the match perspective versus self-determination theory, Journal of Educational Psychology, 100(2), pp. 387-397. https://doi.org/10.1037/0022-0663.100.2.387

Vatcheva, K.P., Lee, M.J., McCormick, J.B. and Rahbar, M.H. (2016), Multi-collinearity in Regression Analyses Conducted in Epidemiologic Studies, Epidemiology (Sunnyvale, Calif), 6(2), pp. 227. https://doi.org/10.4172/2161-1165.1000227

Villoria, M., Van Ryzin, G.G. and Lavena, C.F. (2013), Social and political consequences of administrative corruption: a study of public perceptions in Spain, Public Administration Review, 73(1), pp. 85-94. https://doi.org/10.1111/j.1540$\underline{6210.2012 .02613 . \mathrm{x}}$

Woodberry, R.D. (2008), Pentecostalism and economic development, in: Imber, J.B. (ed.), Markets, morals, and religion, New Brunswick, NJ: Transaction Publishers, pp. 157177. 
Yan, Y. and Qi, S. (2020), I know what I need: optimization of bribery, Journal of Business Ethics, pp. 1-22. https://doi.org/10.1007/s10551-020-04608-Z

Zaloznaya, M. (2014), The social psychology of corruption: why it does not exist and why it should, Sociology Compass, 8(2), pp. 187-202. https://doi.org/10.1111/soc4.12120

Zhang, A. (2009), Corruption as a determinant of transaction governance structure, Strategic Outsourcing: An International Journal, 2(1), pp. 27-36. https://doi.org/10.1108/17538290910935873

Zlotnik, A. and Abraira, V. (2015), A general-purpose nomogram generator for predictive logistic regression models, Stata Journal, 15(2), pp. 537-546. https://doi.org/10.1177/1536867X1501500212 


\section{Appendix}

\section{Table A. The variables and the corresponding questions for this study}

\begin{tabular}{|c|c|c|}
\hline VARIABLE & $\begin{array}{r}\text { QUESTIONNAIRE ITEM } \\
\end{array}$ & CODING \\
\hline \multicolumn{3}{|c|}{ Inherited and background characteristics } \\
\hline inherited_hard_work & Have you inherited the hard work from your parents? & 1-yes,0-no \\
\hline inherited_good_manners & Have you inherited good manners from your parents? & 1 -yes, 0 -no \\
\hline inherited_independence & Have you inherited independence from your parents? & 1-yes, 0 -no \\
\hline inherited_sense_responsibility & Have you inherited from the feeling of responsibility your parents? & 1-yes, 0 -no \\
\hline inherited_tolerance & Have you inherited tolerance from your parents? & 1-yes, 0 -no \\
\hline inherited_perseverance & Have you inherited perseverance from your parents? & 1-yes, 0 -no \\
\hline inherited_obedience & Have you inherited obedience from your parents? & 1-yes, 0 -no \\
\hline inherited_creativity_imaginati & Have you inherited creativity and imagination from vour narents? & 1 -ves 0 -no \\
\hline & Have you inherited creativity and imagination from your parents? & \\
\hline inherited_altruism & Have you inherited altruism from your parents? & 1-yes, 0 -no \\
\hline inherited_respect4elders & Have you inherited respect for the elders from your parents? & 1-yes, 0 -no \\
\hline inherited_respect4traditions & Have you inherited respect for traditions from your parents? & 1-yes, 0 -no \\
\hline clear_lasting_inherited_values & Will these inherited qualities and traits last? & 1-yes,0-no \\
\hline number_siblings & $\begin{array}{l}\text { How many brothers (sisters) do you have? (from } 0 \text { to } 9,0 \text { - no siblings and } 9 \text { - more than } 8 \text { siblings) } \\
\text { What is your household monthly income level? ( } 1 \text {-less than } 1500 \text { RON, } 2-1500-2499, \ldots 7 \text { - more than }\end{array}$ & 10-point Likert scale \\
\hline income_level & $6500 \mathrm{RON})$ & 7-point Likert scale \\
\hline mother_education & What is your mother's highest level of education completed? & years total schooling \\
\hline father_education & What is your father's highest level of education completed? & years total schooling \\
\hline both_parents_private_sector & Have both of your parents worked or are currently working in the private sector? & 1-yes, 0 -no \\
\hline only_mom_private_sector & Only your mother has worked or is currently working in the private sector? & 1-yes, 0 -no \\
\hline only_father_private_sector & Only your father has worked or is currently working in the private sector? & 1-yes, 0 -no \\
\hline both_parents_faith_God & Do both your parents believe in God? & 1-yes, 0 -no \\
\hline only_mother_faith_God & Does only your mother believe in God? & 1-yes,0-no \\
\hline only_father_faith_God & Does only your father believe in God? & 1-yes, 0 -no \\
\hline both_parents_gone_abroad & Have both of your parents been abroad for more than a year? & 1-yes, 0 -no \\
\hline only_mother_gone_abroad & Only your mother has been abroad for more than a year? & 1-yes, 0 -no \\
\hline only_father_gone_abroad & Only your father has been abroad for more than a year? & 1-yes, 0 -no \\
\hline parental_severity & How strict were your parents? (from 1 to 10,1 - very low level and 10 - very high level) & 10-point Likert scale \\
\hline urban & Are you coming from an urban residence environment? & 1-yes, 0 -no \\
\hline
\end{tabular}


Ro

fHEt

MoldInRo

\section{male}

age

avg_HSG

avg_BG

no_books_read_yearly

level_interpersonal_trust high_believe_in_God

trust_atLeast_one_institForm

lab_success_source

ever_worked

searching_job

think_become_entrepreneur

only_strong_connections

evolve_prof

accept_undeserved_state_fin $\mathrm{adv}$

accept_buying_stolen_goods accept_notbuying_public transp_tickets

accept_notpaying_public_taxe $\mathrm{s}$

accept_pay_bribes

\section{(OUTCOME)}

individual_freedom_factor

_progress

clear_stimulating_effect

_competition
Permanent residence in Romania? (based on the indicated location of residence and corresponding coordinates)

Permanent residence in a place once under the occupation of the former Habsburg Empire? Also (based on the indicated location of residence and corresponding coordinates)

Permanent residence in the Republic of Moldova and studying in Romania (UAIC, UBB, ULBS, ASE, or USV)?

Individual characteristics

\section{What is your gender?
How old are you?}

What is the average of your high-school grades? (from 5 to 10, with two decimal positions)

What is the average of your baccalaureate grades? (from 5 to 10 , with two decimal positions)

What is the number of books you read every year?

In general, do you think most people can be trusted? (from 1 to 5, 1 - complete distrust and 5 - complete trust)

Do you believe in God?

Do you trust at least one Romanian institution?

Is labour an important source of success in life and society?

Have you ever worked? (part-time / full-time job / volunteer)

Are you looking for a part-time and full-time job or to get involved as a volunteer?

Are you thinking of becoming an entrepreneur?

Can you evolve professionally in your own country only based on favouritism?

Is it justifiable to receive from the state financial advantages that you would not deserve?

Is it justifiable to accept to buy a stolen good with the excuse that you can't afford a new one?

Is it justifiable to avoid buying public transportation tickets?

Is it justifiable to avoid paying public taxes with the excuse that they are so high?

Is it justifiable to accept to pay bribes in certain situations?

Is individual freedom an important factor of progress?

Does competition stimulate people to be more diligent, productive, and/or innovative? 1-yes, 0 -no

1-yes, 0 -no

1-yes, 0 -no

1-male, 0 -female

years

between 5.00 and

10.00

between 5.00 and

10.00

number of books

5-point Likert scale

1-yes, 0 -no

1 -yes, 0 -no

1-yes, 0 -no

1 -yes, 0 -no

1 -yes, 0 -no

1-yes, 0 -no

1-yes, 0 -no

1-yes, 0 -no

1 -yes, 0 -no

1-yes, 0 -no

1-yes, 0-no

1-yes, 0-no

1-yes, 0-no

1-yes, 0-no 
clear_conviction_state_involv

economy

clear_conviction_state_create

_prosperity

clear_conviction_thrive_state

instit

clear_conviction_prog_taxatio $\mathrm{n}$

_benef

clear_conviction_income_unif distrib_state

clear_conviction_relig_suppor

ted

_state

clear_conviction_individualis

$\mathrm{m}$

_welfare

clear_conviction_democracy_

best

clear_conviction_relig_infl

_politics

Source: Authors' projection.
Should the state involve more in the economy?

Does the state create prosperity for the members of society?

Does a society thrive based on state institutions?

Is progressive taxation beneficial to society?

Should public revenues be uniformly distributed to society by the state?

Should a religious denomination be actively supported by the state?

Is individualism a factor of material welfare?

Is democracy the best government form?

Should religion influence the politics of a country? 1-yes, 0 -no

1-yes, 0 -no

1-yes, 0 -no

1-yes, 0 -no

1-yes, 0 -no

1-yes, 0 -no

1-yes, 0 -no

1-yes, 0-no

1-yes, 0 -no

\section{Table A1.OLS models based on responses of students from CW-RO}

\begin{tabular}{|c|c|c|c|c|c|c|c|c|c|c|c|}
\hline VARIABLE / MODEL & (1) & (2) & (3) & (4) & (5) & (6) & $(7)$ & (8) & (9) & (10) & (11) \\
\hline \multirow{4}{*}{ accept_undeserved_state_fin_adv } & $0.2150 * *$ & & & $0.1844 * *$ & $0.1820 * *$ & $0.1831 * *$ & $0.1880 * *$ & $0.1825^{* *} *$ & $0.1850 * *$ & $0.1786 * *$ & $0.1773 * *$ \\
\hline & & & & $*$ & $*$ & * & $*$ & $*$ & * & $*$ & * \\
\hline & $(0.0358)$ & & & $(0.0342)$ & $(0.0342)$ & $(0.0343)$ & $(0.0342)$ & $(0.0340)$ & $(0.0344)$ & $(0.0341)$ & $(0.0340)$ \\
\hline & & $0.1147 * *$ & & $0.0955^{* *}$ & $0.0932 * *$ & $0.0928 * *$ & $0.0962 * *$ & $0.0957 * *$ & $0.0960 * *$ & $0.0938 * *$ & $0.0901 * *$ \\
\hline \multirow[t]{3}{*}{ accept_buying_stolen_goods } & & & & $*$ & * & * & $*$ & $*$ & * & $*$ & * \\
\hline & & $(0.0213)$ & & $(0.0203)$ & $(0.0202)$ & $(0.0203)$ & $(0.0204)$ & $(0.0202)$ & $(0.0203)$ & $(0.0203)$ & $(0.0200)$ \\
\hline & & & - & - & - & - & - & - & - & - & - \\
\hline clear_stimulating_effect_competit & & & $0.1802 * *$ & $0.1656^{* *}$ & $0.1645^{* *}$ & $0.1631 * *$ & $0.1482^{* *}$ & $0.1531^{* *}$ & $0.1544 * *$ & $0.1603^{* *}$ & $0.1229 * *$ \\
\hline & & & & & & & & & & & \\
\hline & & & $(0.0277)$ & $(0.0272)$ & $(0.0272)$ & $(0.0270)$ & $(0.0267)$ & $(0.0269)$ & $(0.0271)$ & $(0.0273)$ & $(0.0265)$ \\
\hline only_strong_connections_evolve & & & & & $0.0378^{*}$ & & & & & & $0.0418 * *$ \\
\hline
\end{tabular}




\begin{tabular}{|c|c|c|c|c|c|c|c|c|c|c|c|}
\hline _prof & & & & & $(0.0157)$ & & & & & & $(0.0156)$ \\
\hline think_become_entrepreneur & & & & & & $\begin{array}{c}0.0444 * \\
(0.0197)\end{array}$ & & & & & $\begin{array}{l}0.0409^{*} \\
(0.0195)\end{array}$ \\
\hline & & & & & & & - & & & & - \\
\hline $\begin{array}{l}\text { clear_conviction_state_involve } \\
\text { economy }\end{array}$ & & & & & & & $\begin{array}{r}0.0766^{* *} \\
*\end{array}$ & & & & $0.0682 * *$ \\
\hline 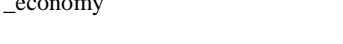 & & & & & & & $(0.0188)$ & & & & $(0.0186)$ \\
\hline & & & & & & & & - & & & \\
\hline & & & & & & & & $0.0501 * *$ & & & \\
\hline clear_conviction_democracy_best & & & & & & & & $*$ & & & $-0.0429 * *$ \\
\hline & & & & & & & & $(0.0141)$ & & & $(0.0140)$ \\
\hline & & & & & & & & & - & & \\
\hline clear_conviction_thrive_state_ins & & & & & & & & & $0.0484 * *$ & & \\
\hline & & & & & & & & & & & $-0.0360 * *$ \\
\hline & & & & & & & & & $(0.0137)$ & & $(0.0137)$ \\
\hline inherited_sense_responsibility & & & & & & & & & & $-0.0596^{* *}$ & $-0.0536^{*}$ \\
\hline & & & & & & & & & & $(0.0224)$ & $(0.0217)$ \\
\hline & $0.0954 * *$ & $0.0902 * *$ & $0.2691 * *$ & $0.2183^{* *}$ & $0.2054 * *$ & $0.2080 * *$ & $0.2605^{* *}$ & $0.2344 * *$ & $0.2306 * *$ & $0.2643^{* *}$ & $0.2963 * *$ \\
\hline constant & & & & & * & * & $*$ & * & * & $*$ & * \\
\hline & $(0.0072)$ & $(0.0075)$ & $(0.0268)$ & $(0.0268)$ & $(0.0273)$ & $(0.0267)$ & $(0.0299)$ & $(0.0274)$ & $(0.0272)$ & $(0.0322)$ & $(0.0350)$ \\
\hline $\mathrm{N}$ & 1862 & 1862 & 1862 & 1862 & 1862 & 1862 & 1862 & 1862 & 1862 & 1862 & 1862 \\
\hline $\mathrm{p}$ & 0.0000 & 0.0000 & 0.0000 & 0.0000 & 0.0000 & 0.0000 & 0.0000 & 0.0000 & 0.0000 & 0.0000 & 0.0000 \\
\hline $\mathrm{R}^{\wedge} 2$ & 0.0383 & 0.0221 & 0.0400 & 0.0881 & 0.0912 & 0.0911 & 0.0984 & 0.0940 & 0.0936 & 0.0929 & 0.1171 \\
\hline $\begin{array}{l}\text { Max.Abs.Val. for Correl.Coef. } \\
\text { (Predictors' Correlation Matrices) }\end{array}$ & 0.0000 & 0.0000 & 0.0000 & 0.1144 & 0.1144 & 0.1144 & 0.1836 & 0.1787 & 0.1640 & 0.1144 & 0.1836 \\
\hline Max OLS computed VIF & 1.0000 & 1.0000 & 1.0000 & 1.0184 & 1.0200 & 1.0189 & 1.0420 & 1.0385 & 1.0340 & 1.0243 & 1.0954 \\
\hline Max OLS acceptable VIF $=1 /(1-$ & & & & & & & & & & & \\
\hline$\left.R^{\wedge} 2\right)$ & 1.0399 & 1.0226 & 1.0417 & 1.0966 & 1.1003 & 1.1003 & 1.1092 & 1.1037 & 1.1032 & 1.1024 & 1.1326 \\
\hline AIC & 967.2684 & $\begin{array}{l}998.4260 \\
1009.484\end{array}$ & 963.9518 & 872.3997 & 868.0286 & 868.0848 & 853.1099 & 862.2910 & 863.0846 & 864.5063 & 824.1430 \\
\hline BIC & 978.3273 & 8 & 975.0106 & 894.5173 & 895.6756 & 895.7319 & 880.7570 & 889.9381 & 890.7317 & 892.1533 & 879.4371 \\
\hline
\end{tabular}

Source: Authors' calculations in Stata 16 MP for all specifications/scenarios/models with the progressive inclusion of those three common most important variables (core - first four models) and others (starting from model 5).

Notes: Robust standard errors in parentheses. *,**,*** indicate significance at 5\%, 1\% and 1\%o. The coefficients are raw coefficients from regressions. Max OLS computed VIF < Max OLS acceptable VIF represents further evidence of the lack of collinearity in the models. 
Table A2. OLS models based on responses of students from SE-RO

\begin{tabular}{|c|c|c|c|c|c|c|c|c|c|c|c|}
\hline VARIABLE / MODEL & (1) & (2) & (3) & (4) & (5) & (6) & (7) & (8) & (9) & (10) & (11) \\
\hline accept_undeserved_state_fin_adv & $\begin{array}{r}0.2118^{* * *} \\
(0.0327)\end{array}$ & & & $\begin{array}{r}0.1819^{* * * *} \\
(0.0316)\end{array}$ & $\begin{array}{r}0.1553^{* * * *} \\
(0.0324)\end{array}$ & $\begin{array}{r}0.1825^{* * * *} \\
(0.0315)\end{array}$ & $\begin{array}{r}0.1806^{* * * *} \\
(0.0316)\end{array}$ & $\begin{array}{r}0.1822 * * * \\
(0.0314)\end{array}$ & $\begin{array}{r}0.1832 * * * \\
(0.0315)\end{array}$ & $\begin{array}{r}0.1817^{* * *} \\
(0.0315)\end{array}$ & $\begin{array}{r}0.1569^{* * * *} \\
(0.0320)\end{array}$ \\
\hline accept_buying_stolen_goods & & $\begin{array}{r}0.1252^{* * * *} \\
(0.0182)\end{array}$ & & $\begin{array}{r}0.1154 * * * * \\
(0.0175)\end{array}$ & $\begin{array}{r}0.1023^{* * * * *} \\
(0.0175)\end{array}$ & $\begin{array}{r}0.1152^{* * * *} \\
(0.0175)\end{array}$ & $\begin{array}{r}0.1119 * * * * \\
(0.0174)\end{array}$ & $\begin{array}{r}0.1166 * * * * \\
(0.0174)\end{array}$ & $\begin{array}{r}0.1194 * * * \\
(0.0175)\end{array}$ & $\begin{array}{r}0.1154 * * * * \\
(0.0175)\end{array}$ & $\begin{array}{r}0.1038 * * * * \\
(0.0172)\end{array}$ \\
\hline clear_stimulating_effect & & & & & & & & & & & \\
\hline _competition & & & $\begin{array}{r}-0.1464 * * * \\
(0.0290)\end{array}$ & $\begin{array}{r}-0.1206^{* * *} \\
(0.0284)\end{array}$ & $\begin{array}{r}-0.1143 * * * \\
(0.0281)\end{array}$ & $\begin{array}{r}-0.1154 * * * \\
(0.0280)\end{array}$ & $\begin{array}{r}-0.1159 * * * \\
(0.0285)\end{array}$ & $\begin{array}{r}-0.1175 * * * \\
(0.0281)\end{array}$ & $\begin{array}{r}-0.1193 * * * \\
(0.0283)\end{array}$ & $\begin{array}{r}-0.1201 * * * \\
(0.0283)\end{array}$ & $\begin{array}{r}-0.1012^{* * * *} \\
(0.0274)\end{array}$ \\
\hline accept_notpaying_public_taxes & & & & & $\begin{array}{r}0.0985^{* * * *} \\
(0.0227)\end{array}$ & & & & & & $\begin{array}{r}0.0935^{* * * *} \\
(0.0226)\end{array}$ \\
\hline $\begin{array}{l}\text { clear_conviction_state_involve } \\
\text { _economy }\end{array}$ & & & & & & $\begin{array}{r}-0.0457 * * \\
(0.0162)\end{array}$ & & & & & $\begin{array}{r}-0.0442 * * \\
(0.0161)\end{array}$ \\
\hline level_interpersonal_trust & & & & & & & $\begin{array}{r}-0.0217 * * \\
(0.0077)\end{array}$ & & & & $\begin{array}{r}-0.0186^{*} \\
(0.0076)\end{array}$ \\
\hline inherited_hard_work & & & & & & & & $\begin{array}{r}-0.0669 * * * \\
(0.0143)\end{array}$ & & & $\begin{array}{r}-0.0556 * * * \\
(0.0146)\end{array}$ \\
\hline inherited_altruism & & & & & & & & & $\begin{array}{r}-0.0542^{* * * *} \\
(0.0132)\end{array}$ & & $\begin{array}{r}-0.0395 * * \\
(0.0133)\end{array}$ \\
\hline only_mother_faith_God & & & & & & & & & & $\begin{array}{r}-0.0345^{*} \\
(0.0136)\end{array}$ & $\begin{array}{r}-0.0324 * \\
(0.0134)\end{array}$ \\
\hline constant & $\begin{array}{r}0.0959 * * * \\
(0.0067) \\
\end{array}$ & $\begin{array}{r}0.0824 * * * \\
(0.0070) \\
\end{array}$ & $\begin{array}{r}0.2468 * * * \\
(0.0281) \\
\end{array}$ & $\begin{array}{r}0.1747 * * * \\
(0.0280) \\
\end{array}$ & $\begin{array}{r}0.1573 * * * \\
(0.0278) \\
\end{array}$ & $\begin{array}{r}0.2038 * * * \\
(0.0309) \\
\end{array}$ & $\begin{array}{r}0.2243 * * * \\
(0.0332) \\
\end{array}$ & $\begin{array}{r}0.2125^{* * *} \\
(0.0294) \\
\end{array}$ & $\begin{array}{r}0.1920 * * * \\
(0.0284) \\
\end{array}$ & $\begin{array}{r}0.1855^{* * *} * \\
(0.0284) \\
\end{array}$ & $\begin{array}{r}0.2827 * * * \\
(0.0366) \\
\end{array}$ \\
\hline $\mathrm{N}$ & 2137 & 2137 & 2137 & 2137 & 2137 & 2137 & 2136 & 2137 & 2137 & 2137 & 2136 \\
\hline $\mathrm{p}$ & 0.0000 & 0.0000 & 0.0000 & 0.0000 & 0.0000 & 0.0000 & 0.0000 & 0.0000 & 0.0000 & 0.0000 & 0.0000 \\
\hline & 0.0383 & 0.0302 & 0.0204 & 0.0775 & 0.0905 & 0.0814 & 0.0789 & 0.0878 & 0.0841 & 0.0800 & 0.1103 \\
\hline $\begin{array}{l}\text { Max.Abs.Val. for } \begin{array}{c}\text { Correl.Coef. } \\
\text { (Predictors' Correlation Matrices) }\end{array}\end{array}$ & 0.0000 & 0.0000 & 0.0000 & 0.1369 & 0.2256 & 0.1369 & 0.1334 & 0.1369 & 0.1369 & 0.1369 & 0.2233 \\
\hline Max OLS computed VIF & 1.0000 & 1.0000 & 1.0000 & 1.0242 & 1.0832 & 1.0258 & 1.0231 & 1.0242 & 1.0244 & 1.0242 & 1.0881 \\
\hline Max OLS acceptable VIF $=1 /\left(1-\mathrm{R}^{\wedge} 2\right)$ & 1.0398 & 1.0311 & 1.0208 & 1.0840 & 1.0995 & 1.0886 & 1.0857 & 1.0963 & 1.0918 & 1.0870 & 1.1240 \\
\hline AIC & 1126.4650 & 1144.3528 & 1165.8909 & 1041.4747 & 1013.2279 & 1034.4309 & 1033.0752 & 1019.4234 & 1028.1906 & 1037.6096 & 969.0854 \\
\hline BIC & 1137.7993 & 1155.6871 & 1177.2252 & 1064.1433 & 1041.5637 & 1062.7667 & 1061.4087 & 1047.7592 & 1056.5264 & 1065.9454 & 1025.7523 \\
\hline
\end{tabular}

Source and Notes are the same as in Table A1.

Table A3. OLS models based on responses of students from RM

\begin{tabular}{|c|c|c|c|c|c|c|c|c|c|}
\hline VARIABLE / MODEL & (1) & (2) & (3) & (4) & (5) & (6) & (7) & (8) & (9) \\
\hline accept_undeserved_state_fin_adv & $\begin{array}{r}0.1989^{* * * *} \\
(0.0281)\end{array}$ & & & $\begin{array}{r}0.1504^{* * *} * \\
(0.0272)\end{array}$ & $\begin{array}{r}0.1241 * * * * \\
(0.0277)\end{array}$ & $\begin{array}{r}0.1481 * * * * \\
(0.0270)\end{array}$ & $\begin{array}{r}0.1477 * * * * \\
(0.0274)\end{array}$ & $\begin{array}{r}0.1211^{*} * * \\
(0.0277)\end{array}$ & $\begin{array}{r}0.1227 * * * \\
(0.0275)\end{array}$ \\
\hline accept_buying_stolen_goods & & $\begin{array}{r}0.3186 * * * \\
(0.0299)\end{array}$ & & $\begin{array}{r}0.2849 * * * \\
(0.0302)\end{array}$ & $\begin{array}{r}0.2660^{* * * *} \\
(0.0305)\end{array}$ & $\begin{array}{r}0.2867 * * * \\
(0.0301)\end{array}$ & $\begin{array}{r}0.2854 * * * \\
(0.0302)\end{array}$ & $\begin{array}{r}0.2688^{*} * * \\
(0.0304)\end{array}$ & $\begin{array}{r}0.2681 * * * \\
(0.0304)\end{array}$ \\
\hline clear_stimulating_effect_competition & & & $\begin{array}{r}-0.1702 * * * * \\
(0.0397)\end{array}$ & $\begin{array}{r}-0.1029 * * \\
(0.0375)\end{array}$ & $\begin{array}{r}-0.0979 * * \\
(0.0368)\end{array}$ & $\begin{array}{r}-0.0861^{*} \\
(0.0384)\end{array}$ & $\begin{array}{r}-0.0987 * * \\
(0.0376)\end{array}$ & $\begin{array}{r}-0.0799 * \\
(0.0379)\end{array}$ & $\begin{array}{r}-0.0830 * \\
(0.0377)\end{array}$ \\
\hline accept_notpaying_public_taxes & & & & & $\begin{array}{r}0.1385^{* * * *} \\
(0.0291)\end{array}$ & & & $\begin{array}{r}0.1330 * * * \\
(0.0291)\end{array}$ & $\begin{array}{r}0.1349 * * * \\
(0.0292)\end{array}$ \\
\hline
\end{tabular}




\begin{tabular}{|c|c|c|c|c|c|c|c|c|c|}
\hline individual_freedom_factor_progress & & & & & & $\begin{array}{r}-0.0774 * \\
(0.0312)\end{array}$ & & $\begin{array}{r}-0.0690^{*} \\
(0.0310)\end{array}$ & $\begin{array}{r}-0.0688^{*} \\
(0.0310)\end{array}$ \\
\hline MoldInRo & & & & & & & $\begin{array}{r}-0.0481 \\
(0.0329)\end{array}$ & $\begin{array}{r}-0.0360 \\
(0.0323)\end{array}$ & \\
\hline $\mathrm{N}$ & 1073 & 1073 & 1073 & 1073 & 1073 & 1073 & 1073 & 1073 & 1073 \\
\hline $\mathrm{p}$ & 0.0000 & 0.0000 & 0.0000 & 0.0000 & 0.0000 & 0.0000 & 0.0000 & 0.0000 & 0.0000 \\
\hline $\mathrm{R}^{\wedge} 2$ & 0.0483 & 0.1141 & 0.0202 & 0.1508 & 0.1717 & 0.1563 & 0.1523 & 0.1768 & 0.1760 \\
\hline $\begin{array}{lll}\text { Max.Abs.Val. } & \text { for } & \text { Correl.Coef. } \\
\text { (Predictors' Correlation Matrices) } & \end{array}$ & 0.0000 & 0.0000 & 0.0000 & 0.1479 & 0.2173 & 0.1868 & 0.1479 & 0.2173 & 0.2173 \\
\hline Max OLS computed VIF & 1.0000 & 1.0000 & 1.0000 & 1.0363 & 1.0711 & 1.0608 & 1.0365 & 1.0800 & 1.0747 \\
\hline Max OLS acceptable VIF $=1 /\left(1-R^{\wedge} 2\right)$ & 1.0508 & 1.1288 & 1.0207 & 1.1776 & 1.2073 & 1.1852 & 1.1796 & 1.2148 & 1.2136 \\
\hline AIC & 1253.9675 & 1177.1437 & 1285.1765 & 1135.7200 & 1110.9771 & 1130.8095 & 1135.8471 & 1108.3109 & 1107.3888 \\
\hline BIC & 1263.9239 & 1187.1001 & 1295.1329 & 1155.6328 & 1135.8681 & 1155.7005 & 1160.7382 & 1143.1584 & 1137.2581 \\
\hline
\end{tabular}

Source and Notes are the same as in Table A1.

\section{Online Appendix}

Figure A-O1. GFT based distribution of responses filtered or not using the outcome variable (online at: https://ejes.uaic.ro/appendix/EJES2020_1201_PLO_A01.tiff, and https://y2u.be/iMer7KgWZoU)

Figure A-O2. GFT based representation of the polygon corresponding to territory once under the former occupation of the former Habsburg empire (online at: https://ejes.uaic.ro/appendix/EJES2020_1201_PLO_A02.tiff)

Figure A-O3. Short representation of the Point-in-Polygon technique used to determine responses inside the polygon above (online at: https://tinyurl.com/47sc9zsa, and https://ejes.uaic.ro/appendix/EJES2020_1201_PLO_A03.jpg)

Figure A-04. Results of many data mining tests performed using the Naïve Bayes techniques (online at: https://ejes.uaic.ro/appendix/EJES2020_1201_PLO_A04.pdf) 